\title{
EL CENSO DE LA POBLACIÓN DE ESPAÑA DE 1860. PROBLEMAS METODOLÓGICOS. INICIO DE LA APORTACIÓN SOCIAL EN LOS CENSOS
}

\author{
Vicente Gozálvez Pérez \\ Vicente.gozalvez@ua.es \\ Gabino Martín-Serrano Rodríguez \\ Gabino.martin@ua.es \\ Departamento de Geografía Humana \\ Universidad de Alicante
}

\section{RESUMEN}

Entre los países occidentales, España se incorpora con dierto retraso a la confección de sus primeros censos modernos de población. La Comisión de Estadística general del Reino -creada en 1856- se muestra muy lejos de la autoindulgencia respecto a los resultados de sus trabajos geodemográficos iniciales. Para sus dos primeros censos (1857 y 1860) la Comisión sólo ofrece la población de hecho, no define adecuadamente la valoración de la población económicamente activa, y, sobre todo, confiesa su insuficiente credibilidad respecto a la exhaustividad de la población empadronada. La segunda parte del artículo estudia una de las primeras variables sociales introducidas en los censos, la frecuentación escolar y la alfabetización; en ambos casos son determinantes las acusadas diferencias de género, de habitat y territoriales.

Palabras clave: Censo de población 1860, España, problemas metodológicos, escolarización, alfabetización, discriminación educativa femenina.

\section{ABSTRACT}

The production of the first modern population censuses in Spain began with relative delay. The Spanish Statistics Commission - created in 1856 - is far from being autoindulgent when it comes to the results of its original geodemographic works. In its first two censuses

Fecha de recepción: marzo 2014.

Fecha de aceptación: diciembre 2014. 
(1857 and 1860), the Commission only offered the de facto population. It did not adequately define the concepts of economically active population and recognised its lack of credibility regarding the exhaustiveness of the registered population. The second part of the article studies one of the first social variables to be introduced in the census: school enrolment and literacy. In both cases, there are marked diferences in gender as a result of the discrimination against girls and women in education.

Keywords: Population census 1860, Spain, methodological problems, school enrolment, literacy, discrimination against women in education

\section{INTRODUCCIÓN}

El texto que sigue indaga sobre dos de los aspectos fundamentales del Censo de la población de España de 1860. En primer lugar sobre sus problemas metodológicos, sobre todo el grado de exhaustividad conseguido en el empadronamiento de la población. La Comisión de Estadística creada a finales de 1856 se muestra muy lejos de la autoindulgencia cuando tiene que evaluar los resultados que ha conseguido tanto en los dos primeros censos modernos de la población de España realizados en 1857 y 1860, como en las estadísticas de movimiento natural de la población. Estas últimas inician su publicación en 1858, con las cifras de bautizados, matrimonios y defunciones, aportadas por los párrocos a partir de los libros sacramentales que están bajo su control. A la Comisión de Estadística le merecen credibilidad insuficiente por omisiones las cifras absolutas aportadas tanto en los censos como en el movimiento natural. Además, la Comisión también denuncia otras deficiencias metodológicas notorias, como son no haber recogido en los censos la población de derecho, ni haber clarificado lo suficiente las definiciones y contabilidad de la población activa; e igualmente hecha en falta algunas estructuras elementales que deberían acompañar a las cifras absolutas de movimiento natural, como son la edad de los que fallecen o las causas de las muertes, así como la necesaria sustitución de bautizados por nacimientos, pues los primeros -únicas cifras que se obtuvieron hasta la implantación del Registro Civil en 1871- no recogen a los niños que mueren antes de ser bautizados.

La incertidumbre de la Comisión de Estadística sobre la exhaustividad de los primeros recuentos censales tiene numerosas causas, entre las que se podrían destacar, a) la lejanía -70 años- del censo pre-moderno de la población de España realizado en 1787, lo que impedía tener un recuento previo fiable que sirviera de comparación para el censo de 1857 , o b) la falta de infraestructura estadística censal en España -sobre todo a escala provincial-, pues la Comisión de Estadística se crea sólo unos meses antes de ejecutar el primer censo moderno de España. Así, las dudas y desconfianza sobre los resultados del censo de 1857, llevan a su diseño y publicación sólo con variables demográficas elementales (Melón, 1951), mientras la Comisión pretende su validación -o no- mediante la realización de un segundo censo sólo tres años después. El censo de 1860 ya cuenta con variables sociales (niveles de instrucción, población activa) fundamentales para conocer la realidad del país a efectos aplicados; es decir para mejorar su gobernabilidad y su desarrollo económico, social, cultural, político..., que son finalidades del censo buscadas por todos los gobiernos, y que justifican estas grandes y costosas operaciones estadísticas. 
La segunda parte de este texto se centra en el estudio del nivel de instrucción básica o primaria de la población de España a escala provincial. Además de los desiguales niveles de alfabetización alcanzados según género, hábitat y territorios, también se incluye el análisis de algunas de las infraestructuras humanas necesarias para alcanzar los niveles de instrucción existentes, como son la escasa y desigual dotación de maestros y maestras de enseñanza primaria y, sobre todo, los niveles de frecuentación escolar, tan determinados entonces por la clase social de los cabezas de familia así como por la discriminación femenina en lo que concierte a la educación. Las estadísticas del censo de 1860 y la misma Ley de Instrucción Pública de 1857, son testigos de excepción de dicha discriminación. El estudio destaca las profundas disparidades existentes en escolarización y en alfabetización entre varones y mujeres, tanto en su hábitat urbano como sobre todo en el rural, así como en su distribución regional.

La información sobre el nivel de alfabetización es, para la época, la novedad social más trascendente del Censo de 1860, aunque se ofrezca con una grave carencia -en parte subsanable- como es la falta de asociación entre los alfabetizados y su edad. El estudio de los niveles de alfabetización según género, hábitat y territorios, entronca de lleno con la finalidad social y aplicada que en la época se buscaba por los Gobiernos de todos los países para justificar sus censos modernos. España en 1860 era un país rural por su hábitat, agrario por su empleo, y en buena parte analfabeto por su nivel de instrucción; el analfabetismo alcanza niveles extremos entre las mujeres de la mayor parte del país, situación muy vinculada a la discriminación femenina. En efecto, tanto el Censo de población de 1860 como la misma Ley de Instrucción Pública de 1857 (Ley Moyano) denuncian y sancionan, respectivamente, graves hechos de discriminación para la mujer en materia de educación primaria, tanto entre docentes como entre discentes, lo que repercute en los distintos niveles de alfabetización alcanzados por uno y otro sexo.

Comprender la realidad social y económica del momento en España y evaluar sus necesarios cambios a corto y medio plazo en las diversas regiones del país, sin duda requieren el estudio geográfico de la variable educativa primaria, de sus acusados déficits y de sus profundas desigualdades de género y territoriales. Conocer el nivel de instrucción básico en la España de 1860, resulta crucial, no sólo para explicar la situación social, económica o política en el momento censal, sino también para prever y planificar el avance hacia un mayor progreso interno del país y en el contexto de los países del entorno europeo.

\section{PROBLEMAS METOdOLÓGICOS EN LOS CENSOS DE LA POBLACIÓN DE ESPAÑA DE 1857 Y 1860}

Los censos modernos de la población de España se iniciaron con notable retraso respecto a los de países más desarrollados occidentales. Pese a las teóricas ventajas que podrían proporcionar las primeras experiencias censales extranjeras, el retraso de los dos primeros censos de España no parece haberlas aprovechado en todas sus posibilidades, pues la experiencia española se inicia con cierto grado de precipitación, tanto en la creación de las necesarias infraestructuras estadísticas censales, como en sus consecuencias más negativas, como son la inseguridad oficial sobre la exhaustividad del empadronamiento o en la definición adecuada de contenidos censales fundamentales, como son la población de derecho, la declaración de actividad económica o la edad en los escolares y alfabetizados. 


\section{II.1. Insuficiente credibilidad oficial sobre las primeras estadísticas geodemográficas}

La Comisión de Estadística general del Reino, creada por Real Decreto de 3 de noviembre de 1856 (INE, 1981), realiza el primer Censo de población de España con referencia al 21 de mayo de 1857, publicado en 1858. La misma Comisión publica en 1859 el primer Anuario estadístico de España, con referencia al año 1858. Asimismo, el Movimiento [natural] de la población de España -bautismos, matrimonios, defunciones- inicia su publicación en la segunda edición del anuario (Anuario Estadístico de España de 1859 y 1860 , publicado en 1860), con datos referidos a los años 1858 y 1859, para España, las provincias y sus capitales. Por su parte, la Junta General de Estadística del Reino ${ }^{1}$ publicaba en 1863 la primera Memoria sobre el Movimiento de la población de España referida a los años 1858, 1859, 1860 y 1861; aunque esta Memoria también incluye las estadísticas de movimiento natural del año 1862, al haberse recogido éstas antes de concluir «la penosa impresión del periodo de los cuatro años [de movimiento natural de la población] a que debió limitarse» esta Memoria (p. 67).

Las publicaciones estadísticas señaladas tienen una característica común muy llamativa: la desconfianza confesa por la Comisión sobre las estadísticas demográficas, es decir el Censo de la población de 1857 y, sobre todo, el movimiento natural de la población²; esta

1 La Comisión de Estadística General del Reino, creada el 3-XI-1856, inicialmente dividió sus tareas en cuatro secciones: Territorio, Población, Producción e Impuestos. El 21 de abril de 1861, la Comisión se transforma en una nueva institución denominada Junta General de Estadística, que hereda el personal y las competencias de la Comisión, al mismo tiempo que sus cometidos se amplían notablemente en operaciones estadísticas y cartográficas, y aumenta su capacidad ejecutiva. La organización funcional de la nueva Junta abarca: Secretaría General, Operaciones censales, Operaciones geodésicas, Mapas especiales, Operaciones topográfico-catastrales. Estas transformaciones coinciden con un momento dorado en disponibilidad de medios económicos: en 1860 el presupuesto de la Comisión-Junta era de 2,9 millones de pesetas, pero ya en 1863-1864, el presupuesto se reduce en más de un millón, en 1864-65 queda fijado en 1,3 millones, y en 1866-67 se rebaja a 800.000 pesetas. En esta situación de penuria -por el fuerte endeudamiento del Gobierno- se han de interrumpir numerosos trabajos de la Junta en cartografía geológica, forestal, hidrológica, ... y también se aplaza la realización del censo de población de 1865, ya previsto desde el R.D. de 30 de septiembre de 1858; asimismo esta crisis presupuestaria redujo a la condición de cesantes a numerosos funcionarios de la Junta (Nadal, Muro, Urteaga, 1996: 80-87).

2 Las estadísticas de movimiento natural de la población (bautismos [por nacimientos], defunciones y matrimonios), inicialmente suministradas por los párrocos, podrían haber sido fidedignas en sus cifras absolutas, dada la importancia de estos actos religiosos para los feligreses y por su control en las parroquias (administración de sacramentos, en el caso de bautismos y matrimonios; aplicación del derecho eclesiástico, en el caso de parentesco entre cónyuges; trascendencia espiritual de la muerte para el cristiano, y posibles efectos económicos positivos para las parroquias en caso de donaciones de los difuntos, hechas en vida, etc.).

En las estadísticas de movimiento natural con origen en los libros sacramentales de las parroquias, hay que distinguir, por una parte, el valor de la fuente en origen, sin duda muy alto por las razones indicadas, lo que era reconocido por las autoridades estadísticas nacionales (Gozálvez, 1986); y por otra parte, la fiabilidad de estas mismas estadísticas que desciende - por omisiones- cuando los párrocos han de entregar sus cifras a las autoridades civiles, para su posterior publicación; la desconfianza eclesial podía ser extrema (Gozálvez, 1986). En cualquier caso, las cifras de bautizados no se corresponden con las de nacidos, pues aquéllos no incluyen ni los nacidos muertos, ni los nacidos vivos pero fallecidos antes de recibir el bautismo.

La primera publicación de movimiento natural con origen en los libros sacramentales de las parroquias, lo realiza la Junta General de Estadística para los años 1858 y 1859 en el Anuario Estadístico de España de 1860: 1861, estadísticas que se repiten y se amplían con los años 1860, 1861 y 1862 en la Memoria sobre Movimiento de la población de España, igualmente bajo la responsabilidad de la Junta General de Estadística. En esta segunda publicación, además de una «Exposición» o introducción, se incluye un amplio apartado que recopila las «leyes, 
valoración de la Comisión, por motivos muy variados, se prolongará para el movimiento natural durante más de medio siglo (Burriel de Orueta, 1980; Gozálvez Pérez, 1986).

El Censo de la población de España de 1857 cuenta con una introducción firmada por el Presidente del Consejo de Ministros, Leopoldo O-Donnell, que también ostentaba la Presidencia de dicha Comisión, en la que se realiza (p. V-XI) un profundo examen crítico sobre los resultados de este primer censo, es decir se muestra muy lejos de la autoindulgencia. En efecto, esta introducción destaca:

a) El Censo no alcanza «la seguridad de una exactitud completa», debido a la falta de experiencia en este tipo de trabajos; «el censo actual [1857], considerado como ensayo y punto de partida». De hecho, en el Censo de población de 1860 quedan patentes las ansias de comprobar la exactitud numérica de la población censada, para lo que el segundo censo publica tablas provinciales comparativas de la población entre 1857 y 1860. Para justificar las variaciones numéricas intercensales de los habitantes, se insiste en la necesidad de disponer de un registro civil que validara, mediante los nacimientos y defunciones registrados en el intercensal, las variaciones positivas o negativas en el número de habitantes censados. En este sentido, el censo de 1860 también incluye la publicación de unas breves «notas» sobre los motivos que han provocado que un número indeterminado de municipios de cada provincia censaran menos habitantes en 1860 que en 1857 -más adelante se ofrece un epígrafe que comenta estas «notas»-. El total nacional de habitantes para la península y archipiélagos de Baleares y Canarias en 1857 fue de 15.464.340, sobre lo que la Comisión de Estadística afirma que «no está penetrada de la rigurosa precisión de esta suma; piensa al contrario que debiera resultar mayor». La sospecha de no haber censado el total real de la población, la achaca la Comisión, por una parte, a las provincias con población muy diseminada, que exigirían mayor preparación de las operaciones censales, y, por otra, a no haber censado todos los hogares colectivos de las ciudades mayores. De cualquier forma, «al Censo le asiste el derecho de ser reputado verdad en el orden legal, aún cuando no lo sea en el estricto orden material» (p. VIII).

b) Las profesiones y ocupaciones, aunque sí figuraban en el impreso de empadronamiento del Censo de 1857, no llegaron a publicarse «...por la complicación resultante de figurar una misma persona repetidamente y por varios conceptos en las casillas de los padrones, por lo que la Comisión... hubo de renunciar por ahora a semejante averiguación, después de reiterados e inútiles esfuerzos por obtenerla».

decretos, reales órdenes y circulares... que se refieren al movimiento natural de la población. Esta documentación legal se retrotrae a 23 de junio de 1813, fecha en la que ya se intenta que los párrocos entreguen en los ayuntamientos, con destino al Jefe político de cada provincia, una estadística trimestral con los «nacidos, casados y muertos en el pueblo, con especificación de sexos y edades», así como una noticia de las enfermedades por las que han fallecido, «extendida por el facultativo o facultativos». La parte esencial de esta segunda publicación hace honor a su título, es decir la Junta General de Estadística realiza una amplia Memoria sobre la fiabilidad de las cifras de los tres componentes del movimiento natural suministrados por los párrocos -bautismos, matrimonios, defunciones-, sobre todo comparando las variaciones interanuales de las cifras provinciales, y señalando las causas que posiblemente pueden influir en esas variaciones. La Junta insiste en la necesidad de formar un registro civil, independiente de las cifras de los eclesiásticos, que mejore la fiabilidad de los datos aportados por los párrocos, y sobre todo para que se aumenten los contenidos informativos de cada uno de los componentes del movimiento natural. 
c) También por razones «técnicas», la Comisión hubo de renunciar a la publicación de la población de derecho, dando por suficiente con la de hecho: «Igualmente ha sido preciso prescindir de apurar el domicilio legal de cada uno de los habitantes... la población transeunte y la propiamente flotante se inscriben y abultan donde no les corresponde por título de vecindad; para evitar confusiones... [convendría] el aumento de una casilla en las cédulas de inscripción donde apuntar los vecinos e individuos del pueblo temporalmente ausentes, ...». «El censo [de 1857]... no es completo, porque no consiste en el padrón general de los españoles con especificación de su domicilio de derecho: únicamente contiene el domicilio de hecho en un día dado» (sobre éste y otros temas, vid. Cusidó; Gil-Alonso, 2012).

d) La Comisión destaca los antiguos -y generalizados- problemas de las subdeclaraciones censales ante los temores de que los datos declarados fueran utilizados por la Administración para aumentar los impuestos y/o los cupos de soldados en las diferentes circunscripciones territoriales. Se trata sin duda de un temor de la población censada bien fundado en la experiencia secular de los antiguos recuentos o censos de población. Por otra parte, estos temores de los ciudadanos eran compartidos por todos los países europeos (Horvath, 1991), así como en los colonizados por estos ${ }^{3}$, bien que todos los Gobiernos implantaban los censos modernos convencidos de su absoluta necesidad para el conocimiento del país, lo que resultaba imprescindible para su correcta administración y fomento económico y social ${ }^{4}$.

En el caso del censo de población de España de 1857, en su introducción-presentación se especifica: «... se han advertido algunos resabios, e instintiva repugnancia de los pueblos a investigaciones de toda especie por recelo de vejámenes y nuevos impuestos...», aunque

3 Así, en referencia a la confianza sobre el censo decenal de población de Canadá de 1911 se afirma: «Tradicionalmente, el pueblo resiente la desconfianza hacia los censos y teme que se trate de un medio para imponerles nuevas cargas fiscales». Este censo de 1911 fue concebido y presentado como un modelo, tanto en el plano administrativo como científico (Bellavance; Normand, 2005: 337). Los primeros censos federales realizados en Canadá lo fueron en 1871, 1881 y 1891 (Inwood; James, 2005).

4 Los censos de población modernos deben tener una serie de características, como son: referencia al conjunto del país, empadronamiento nominal y simultáneo, fecha de referencia del censo, periodicidad censal, que las hojas de empadronamiento recojan las principales estructuras demográficas y socioeconómicas de todos los ciudadanos; y todo ello realizado con un soporte administrativo y estadístico suficiente, patrocinado por la Administración del Estado; los censos modernos deben de ser publicados con la información estadística desagregada espacialmente.

Los primeros censos modernos fueron realizados en Finlandia en 1749, en Suecia en 1750, en Dinamarca y Noruega en 1769, en 1790 en Estados Unidos, en 1801 en Francia e Inglaterra, y durante el siglo XIX en el resto de Europa. Inicialmente en Europa se fijaron periodicidades de 5 años para los censos, pero se impuso la periodicidad decenal (Horvath, 1991; Noin, 1988).

En el caso de España, el Gobierno era bien consciente del retraso en la ejecución del primer censo moderno: «Dolor causa decirlo, pero es una verdad por desgracia, que siendo bien conocida la población de casi todas las naciones civilizadas, no lo es la nuestra sino por cálculos tan vagos e inseguros que no merecen la menor confianza» (Exposición a S.M. del Presidente del Consejo de Ministros -y también Presidente de la Comisión de Estadística general del Reino-, D. Ramón María Narváez, con motivo de la presentación del proyecto del Real Decreto -14 marzo de 1857- para regularizar la formación del Censo de población de 1857). La justificación del retraso censal español se vincula con la azarosa vida política de España durante la primera mitad del siglo XIX (Dirección General...: Reseña Geográfica....1888). 
también se señala el reconocimiento general de las ventajas que podrían derivarse del censo -como un mejor reparto de los impuestos-, en lo que sin duda podría haber influido «el Clero [que] ha cooperado con benevolencia». Se advierte en el Censo que las ciudades medianas son las que tienen mayores sospechas de ocultaciones intencionadas y maliciosas, frente a las más pequeñas que han mostrado «ordinariamente más sinceridad» (p. VII-VIII).

e) Para corregir omisiones y errores censales, tal como se hacía en otros países (Bellavance; Normand, 2005), los Gobernadores provinciales de España publicaron en los Boletines oficiales avances del censo, y «se invitó a los individuos y a los pueblos a reclamar de agravios como a denunciar ocultaciones, y por espacio de algunos meses se practicaron diligencias varias, hasta que empezaron a dar por terminadas...».

f) Finalmente, en la introducción del Censo de 1857, se reitera la utilidad y el carácter aplicado con que nace el Censo de población: «El Censo debe producir en todos los ramos de la administración pública el efecto de servir de regulador legal de la población, el de promover las reformas útiles que aconseje la prudencia deducidas de los datos en él contenidos, y el de estimular constantemente a la progresiva mejora de este importante trabajo». En concreto, este Censo sustituirá a otros anteriores para la aplicación de la ley electoral, para las quintas, para la Hacienda pública, así como en los Gobiernos provinciales. Asimismo el Censo podrá ser origen para «la reforma de la organización municipal en poblaciones de escaso vecindario», o para agrupar municipios dentro de una misma división territorial administrativa y judicial. En la introducción del Censo también se destaca su utilidad para la empresa privada: «Los datos estadísticos... arrojan luz... para el desarrollo de la industria privada... en el ámbito de la producción y el consumo... que tiene su base en el conocimiento de la población»».

El Censo publicado en 1857 recoge sólo los datos elementales de la población, como son la clasificación de habitantes por provincias, partidos judiciales y municipios -«ayuntamientos»-, distinguiendo naturaleza (nacionales y extranjeros, y para cada grupo «establecidos» y «transeúntes»), estado civil (solteros, casados, viudos) y edades; para cada una de las estructuras indicadas, siempre se especifica el sexo. Los grupos de edades ofrecidos son quinquenales, decenales y anual, para el primer año de vida, pero también conserva dos grupos de edad irregulares, de 1 a 7 años, y de 8 a 15, sin duda herencia de la influencia de los eclesiásticos en la elaboración de los dos censos «premodernos» del siglo XVIII, es decir los censos de 1768 y de $1787^{5}$.

5 El censo de 1768 fue realizado por orden del Conde de Aranda pero ejecutado por la Iglesia, es decir obispos y párrocos. El censo de 1787 fue ordenado por el Conde de Floridablanca a los Intendentes y ejecutado a nivel municipal por las autoridades civiles, aunque éstas irían «acompañadas del Cura», que también «asistiría» al corregidor o diputados del ayuntamiento para formar la estadística municipal con destino al Intendente. Estos dos censos ofrecen idéntica estructura por edades, en la que distinguen grupos «hasta 7 años» y de 7 a 16, sin duda motivados por sendas aplicaciones pastorales, primera comunión y confirmación, respectivamente, para los feligreses de cada parroquia.

El censo de 1768, al ser ejecutado por la Iglesia, agrupa a los habitantes por demarcaciones eclesiásticas, es decir parroquias y obispados, lo que dificultará su comparación con los resultados del Censo civil de 1787, pues la información de este último se ofrece por provincias e intendencias. Los encargos censales de las autoridades civiles 
Dada la trascendencia del censo para la administración y la economía del país, necesitaba, en opinión de las autoridades estadísticas de España, mejorar en la exhaustividad de su información, en la introducción de nuevas variables en las hojas de empadronamiento, así como establecer su renovación «cada cinco años, y que desde luego conviene empezar repitiendo el recuento en el año 1860, para utilizar la experiencia atesorada».

\section{II.2. Del censo demográfico (1857) al censo demográfico y social (1860)}

El censo de la población de España de 1860 -publicado en 1863- se realizó en una «coyuntura estadística» favorable, pues, aparte de la experiencia acumulada por la Comisión de Estadística en la ejecución del censo de 1857, los medios económicos, humanos y administrativos de dicho organismo eran entonces positivos. Así, en 1860 el presupuesto económico de la Comisión fue alto, mientras la crisis financiera del Gobierno afectó gravemente a la Comisión a partir de 1864. El factor humano también fue favorable, pues la preparación y ejecución del Censo de 1860 contó con las capacidades, entre otros, de dos experimentados directivos de la Comisión: el historiador y polígrafo José Caveda y el geógrafo Fermín Caballero, profesor de geografía de la Universidad de Madrid y antiguo Ministro de la Gobernación. En el aspecto administrativo, la Comisión de Estadística organizó Comisiones y Secciones provinciales de Estadística, dirigidas por funcionarios propios, mientras también se sirvió de la infraestructura de los Gobiernos civiles provinciales para ejecutar disposiciones de la Comisión Central de Estadística (Nadal; Muro; Urteaga, 1996). La organización de la administración estadística provincial es sin duda pieza clave para el éxito o el fracaso del conjunto de la operación censal: así, en 1860 las variaciones demográficas provinciales respecto a 1857 (fig. 1), ofrecen cifras que denuncian acusadas omisiones censales en 1857 en las provincias del norte peninsular y en Canarias, pues en el intercensal éstas son las que más crecen (fig. 1), lo que se conjuga mal con su elevadísima emigración transoceánica, tal como se ampliará después; no obstante, como afirma la

a las autoridades eclesiásticas, muestran que esta última institución era la «más asentada, organizada y extendida por todo el territorio, incluso más que el propio Estado» (Ardit; Badenes; Bernat, 2001: 13).

Por otra parte, estos encargos estadísticos a las autoridades eclesiásticas no son nuevos en la España del siglo XVIII, ni son un caso único en Europa. En efecto, un encargo similar queda documentado en el antiguo Reino de Valencia en el año 1646: un Vecindario conservado en el archivo del Reino de Valencia recoge dos recuentos, uno ordenado por el Virrey, que requirió el auxilio de los obispos, que a su vez recababan de los párrocos el trabajo de campo en sus respectivas parroquias; éstos realizaban los listados nominativos de sus vecinos, ya habituales para el control de las obligaciones religiosas de los parroquianos. El segundo recuento incluido en el Vecindario de 1646, se realizó por orden de la Diputación de la Generalitat valenciana, mediante los jurados y justicias de todos los pueblos del Reino. Este segundo recuento, de carácter civil, también relaciona nominalmente a los vecinos. Al comparar ambos recuentos, se observan cifras más bajas en el levantado por los eclesiásticos, quienes, además, insisten en la pobreza de los vecinos; estos pobres con frecuencia alcanzan a un tercio del total de vecinos, sin duda para rebajar así los impuestos que previsiblemente se aplicarían a los feligreses de los párrocos con ocasión de este nuevo recuento (Pérez Puchal, 1972: 13-14).

En este sentido, el Censo de Floridablanca de 1787, en su introducción o «Advertencia» se escribe «... atendiendo al cuidado con que los pueblos y sus vecinos procuran disminuir el número de sus habitantes, temerosos de que tales numeraciones se dirijan a aumentar las cargas de los servicios personales, o de los tributos, ...».

En el caso de Europa, R. Horvath (1991) también señala las «listas de población» eclesiásticas como modelo para las evaluaciones censales de ciudades importantes (Londres a finales del s. XVIII), y más tarde (s. XVIII) para regiones e incluso para el conjunto del país (Prusia, Suecia o el imperio austríaco -excepto Humgría- en 1754). 
Junta de Estadística del Reino en 1863 «... la emigración no [está] consignada por completo en ningún documento» (Memoria sobre el movimiento de la población..., 1863, p. 7). También padecen previsiblemente omisiones censales en 1857, provincias como Ávila (con índice de incremento de $0,95 \%$ anual en el intercensal -España 0,42\%-), Guadalajara $(0,92 \%)$, Albacete $(0,82 \%)$, Castellón $(0,79 \%)$ o las provincias pirenaicas de Lérida $(0,81 \%)$ y Huesca $(0,69 \%)$.

La información publicada del censo de población de 1860 reúne mejoras sustanciales respecto al primer censo de 1857. Estas mejoras son de dos tipos: Por una parte, la información se enriquece en detalle, y por otra, en 1860 se publican dos variables censales nuevas.

En el primer caso se incluye el aumento de los grupos etarios, que pasan de 16 en 1857 a 22 en 1860, lo que beneficia fundamentalmente a los grupos de menores de 25 años; además, en éstos desaparecen los grupos de edad irregulares de 1857, que recordaban la influencia de la Iglesia en la confección de los censos del siglo XVIII al delimitar el grupo infantil -1 a 7 años- con umbral inspirado en la acción pastoral de los párrocos. En 1860 los grupos etarios se regularizan en 1, 4 y 5 años; entre 20 y 25 años de edad la información de 1860 se ofrece en años simples, lo que se vincula con su aplicación militar en el caso de los varones.

Un segundo «enriquecimiento» respecto al censo de 1857, es la publicación en 1860 de las «profesiones, artes y oficios» a escalas de partido judicial y de provincia; esta información también fue recogida en las hojas de empadronamiento de 1857, pero no fue publicada debido a sus deficiencias interpretativas, en opinión de la Comisión de Estadística; entre esas deficiencias, el censo de 1860 destaca la falta de criterios claros en 1857 para contabilizar las frecuentes pluriactividades declaradas por la población activa. No obstante, el censo de 1860 parece que tampoco logró solucionar el problema: «En esta clasifiación [de profesiones, artes y oficios] figuran los habitantes en tantos lugares cuantas eran las profesiones que ejercían al verificarse el recuento» (Censo de la población de España de 1860, p. 758, «Notas, $\left.1^{\mathrm{a}} \gg\right)$. Por otra parte, en las llamadas «profesiones, artes y oficios» del censo de 1860 , además de las profesiones específicas, también se incluyen apartados que actualmente no se valoran como población económicamente activa, como son los niños/as que van a la escuela, «colegiales» de primera y segunda enseñanza, estudiantes universitarios, así como sendos apartados que contabilizan los «pobres de solemnidad», «sordo-mudos» y «ciegos e imposibilitados». En cualquier caso, estos apartados que el Censo «asimila» a la población activa, enriquecen las posibilidades de estudio social y aplicado con que se emprendieron los censos modernos de población.

Entre las variables censales estrictamente nuevas en el censo de 1860, destacan dos: a) El nivel de alfabetización, por sexos, aunque no por edades. La información ofrecida es: «saben leer y escribir», «saben leer y no escribir» y «no saben leer». La trascendencia de esta nueva información es muy alta, pese a las limitaciones que se derivan de la no asociación de este nivel de instrucción primaria con las edades. El conocimiento de la población alfabetizada -sabe leer y escribir- hace posible valorar múltiples aspectos sociales, económicos, culturales, etc., pues la estadística se ofrece por sexos y a escalas municipal, partido judicial y provincias. b) Las «cédulas de inscripción» censal, que son asimilables al concepto actual de hogar; esta información ya ha hecho posible interesantes estudios geohistóricos sobre la estructura familiar a escalas de municipios, partidos judiciales y provincias (Mikelarena, 1992; González Portilla; Urrutikoetxea, 1987). 
La finalidad social de los nuevos censos modernos se resalta por primera vez en el de 1860: se trata de la publicación de once «cuadros» (p. 761-771) elaborados con información significativa socialmente entre la recogida en «profesiones, artes y oficios»; los cuadros ofrecen su estadística a escala provincial, y están referidos a: 1) Cifras absolutas y proporciones entre docentes y alumnos en cada uno de los niveles de enseñanza (universitaria, media y primaria); ésta última también por sexos; 2) Cifras absolutas y proporciones entre población provincial y cada una de las siguientes profesiones: empleados de la administración pública, abogados, escribanos y notarios, médicos y cirujanos; y también por sexo para los artesanos, pobres de solemnidad, sordo-mudos, y ciegos e imposibilitados.

El censo de 1860 también publica 18 «estados» o cuadros (p. 701-719) que resaltan, a escala provincial, distintas clasificaciones de los habitantes; entre ellas se encuentran: densidades demográficas; número de habitantes de las Audiencias territoriales, de los Distritos universitarios, de los Distritos militares y de las Diócesis. También se publican cinco «estados» que comparan por provincias las variaciones de habitantes entre los censos de 1857 y 1860 , en sus cifras totales y por sexos, así como en sus estructuras referidas a «naturaleza» nacional o extranjera, y por su estado civil (solteros, casados y viudos).

\section{II.3. Las variaciones de la población censada entre 1857 y 1860}

La reiterada desconfianza de la Comisión de Estadística hacia los resultados del censo de población de 1857, estuvo influida por numerosas causas, tal como se ha indicado en el epígrafe II.1., sobre todo por:

a) La insuficiente infraestructura estadística, tanto humana como administrativa; estas carencias se juzgan evidentes en relación a casi todos los países occidentales, pues éstos inician su producción de estadísticas demográficas modernas medio siglo antes, e incluso un siglo largo en los países europeos nórdicos (Noin, 1988); además, en 1857 España carecía de censos evolutivos fiables con los que establecer comparaciones, pues la referencia más próxima era el censo de población de 1787 (Censo ordenado en 1786 por el Conde Floridablanca, Ministro de Carlos III), es decir, realizado 70 años antes.

b) Deficiencias técnicas cometidas por la Comisión de Estadística que llevan, por una parte, a desistir de la publicación de la población económicamente activa, y por otra, a no disponer de la población de derecho.

En consecuencia con lo indicado, el Censo de población de 1860 debía corregir las deficiencias «primerizas» del censo de 1857. Sin embargo, el censo de 1860 cambió la fecha censal, que pasa de 21 de mayo de 1857 a 25 de diciembre de 1860, lo que podía dificultar la comparación de los resultados de ambos censos. En efecto, al ofrecer ambos censos sólo la población de hecho, ésta podía verse afectada notablemente por el cambio de fecha censal debido a la importancia de las migraciones laborales de temporada, sin duda muy cuantiosas a resultas del elevadísimo empleo agrario asalariado. En efecto, en 1860 la actividad agraria afecta a casi dos tercios de todos los activos; además, el 54\% de los 4,3 millones que trabajan en el sector primario son jornaleros del campo, y por tanto muy sujetos a las migraciones 
de temporada -según los calendarios agrícolas-, tanto interiores como exteriores, lo que repercute en la contabilidad de la población de hecho. En este sentido, el 21 de mayo era fecha muy propicia para los desplazamientos de temporada a causa del inicio del ciclo de los trabajos agrícolas de recolección de cosechas; en cambio, el 25 de diciembre ocurre lo contrario, es época de paralización para la mayor parte del empleo agrícola. De hecho, según las «notas» sobre causas del descenso de población municipal en 1860 respecto a 1857, publicadas en el censo de 1860, el cambio de fecha censal lleva a muchos ayuntamientos a atribuir su modificación censal negativa a este cambio de fechas censales, y a las correspondientes migraciones de temporada (vid. Apartado II.3.2.).

El total nacional de habitantes censados en 1857 (15.464.078) y en 1860 (15.658.586), muestra un crecimiento global que teóricamente pudiera ser aceptable, tal como se deduce de las moderadas tasas de incremento anual en los distintos intercensales de la segunda mitad del siglo XIX; es decir mientras permaneció el régimen demográfico antiguo, con escaso margen de incremento natural, las distintas tasas fueron inferiores al 0,50\% anual. Por el contrario, los incrementos anuales se sanean durante los intercensales de la primera mitad del siglo XX, a consecuencia del aumento del saldo natural que conlleva la transición demográfica, mientras las migraciones exteriores masivas entre 1880 y 1930 parecen no tener influencia decisiva en las tasas de los incrementos intercensales del conjunto de España:

\begin{tabular}{|r|r|}
\hline \multicolumn{1}{|c|}{ Año } & \multicolumn{1}{|c|}{$\begin{array}{l}\text { Aumento } \\
\text { anual, \% }\end{array}$} \\
\hline 1857 & -- \\
\hline 1860 & 0,42 \\
\hline 1877 & 0,35 \\
\hline 1887 & 0,55 \\
\hline 1900 & 0,46 \\
\hline
\end{tabular}

\begin{tabular}{|r|r|}
\hline \multicolumn{1}{|c|}{ Año } & \multicolumn{1}{|c|}{$\begin{array}{l}\text { Aumento } \\
\text { anual, \% }\end{array}$} \\
\hline 1910 & 0,71 \\
\hline 1920 & 0,68 \\
\hline 1930 & 1,02 \\
\hline 1940 & 0,95 \\
\hline 1950 & 0,78 \\
\hline
\end{tabular}

\section{II.3.1. Las variaciones censales de las provincias}

Las variaciones demográficas provinciales entre 1857 y 1860 tienen credibilidad variada. Por lógica demográfica de saldo natural, la mayoría de las provincias -35 de 49-aumentaron su censo en 1860 (fig. 1), aunque este crecimiento sin duda también está facilitado por la mejor infraestructura censal disponible en 1860, lo que propiciaría la corrección de muchas omisiones censales de 1857. No obstante, la Comisión de Estadística pensaba que la exhaustividad del segundo censo aún no era completa: «Razones hay para suponer que á un número más alto ascienden hoy los habitantes de España, ...» (Introducción del Censo de 1860 , p. IX).

Para explicar los mayores aumentos censales, el de las 14 provincias que alcanzan en el intercensal 1857-1860 tasas anuales entre 0,81\% y 1,66\% -la media de España fue de $0,42 \%$ - parece prudente atribuir la causa, sobre todo, a unas omisiones censales muy notorias en 1857, aunque esta afirmación no se sostenga en los casos de Cádiz ( $0,97 \%$ anual) y Madrid $(0,94 \%)$, donde la inmigración masculina parece tener importancia muy destacada, tal como se deduce de sus elevadas tasas de sex ratio para la población que tiene 11 y más años de edad, pues registran, respectivamente, 113,6 y 109,5 varones por 100 mujeres; el 
puerto de Cádiz y la capitalidad de Madrid son sin duda las causas principales. Por el contrario, los fuertes incrementos censales de las provincias de Pontevedra, Oviedo, Santander, Vizcaya y Lugo, parecen obedecer fundamentalmente a subregistros en el censo de 1857, pues contaban con poblamiento muy diseminado -que dificultaba las labores censales- y estaban afectadas por una intensa emigración, sobre todo hacia América, protagonizada por varones jóvenes (fig. 1 y 6): así, sus altas tasas de crecimiento anual entre 1857 y 1860 quedan «desmentidas» por sus bajísimas tasas de sex ratio en 1860 entre la población con 11 y más años de edad, a causa de su acusada emigración:

\begin{tabular}{|r|r|r|}
\hline Provincia & $\begin{array}{c}\text { Incremento anual en } \\
\text { \%, 1857-1860 }\end{array}$ & $\begin{array}{c}\text { Varones/100 mujeres en } \\
\text { población de 11 y más años } \\
\text { de edad, 1860 }\end{array}$ \\
\hline Pontevedra & 0,88 & 71,0 \\
\hline Oviedo & 1,01 & 77,8 \\
\hline Santander & 0,85 & 83,3 \\
\hline Lugo & 0,65 & 83,9 \\
\hline Vizcaya & 1,66 & 89,9 \\
\hline España & $\mathbf{0 , 4 2}$ & $\mathbf{9 6 , 4}$ \\
\hline
\end{tabular}

Como ya se indicó, otras seis provincias del interior peninsular también registran en 1860 crecimientos más altos de los esperables por su economía y funciones, y achacables, por tanto, a omisiones en el empadronamiento de 1857 (fig. 1).

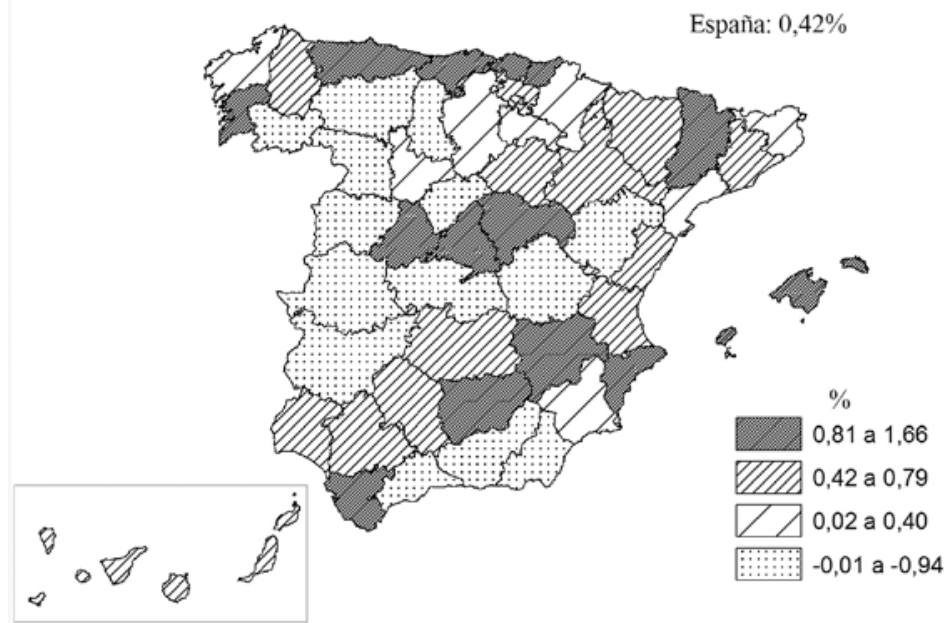

Fuente: Junta General de Estadística: Censos de la población de España de 1857 y 1860. 
En el extremo opuesto de las variaciones censales, otras 14 provincias registran en el intercensal tasas de variación anual negativas, entre $-0,01 \%$ y $-0,94 \%$, pese a los esfuerzos de la Comisión de Estadística por corregir al alza los censos provinciales. Como causas explicativas de estas disminuciones demográficas se puede citar, entre otras, la emigración, igualmente deducida de la baja sex ratio entre su población con 11 y más años de edad; este sería el caso de Orense (87,6 varones por 100 mujeres en 1860), Almería $(89,9)$ o León $(90,6)$. La localización geográfica de las provincias con disminución censal en 1860 (fig. 1), fundamentalmente a lo largo de la frontera con Portugal, puede apoyar su pérdida de población en la emigración por motivos de pobreza y sus secuelas.

\section{II.3.2. Causas de disminuciones censales municipales explicitadas en el censo de 1860}

La «obsesión» de la Comisión de Estadística por corregir/explicar en el segundo censo las omisiones de empadronamiento de 1857, le lleva a publicar en el censo de 1860 unas breves «Notas» a pie de página, situadas en la hoja censal que recoge la estructura demográfica de cada provincia. Estas notas aportan explicaciones muy sintéticas sobre las causas principales que provocan disminución de habitantes en 1860 respecto a 1857 en un número indeterminado de municipios de cada una de las provincias (fig. 2, 3, 4, 5). La fuente original de esta información son, pues, los ayuntamientos ${ }^{6}$.

a) Casi todas las provincias de España registran municipios que disminuyen su censo en 1860 por emigración - definitiva o de temporada-relacionada con el sector agrario, es decir con la agricultura y la ganadería (fig. 2): emigración por malas cosechas (en 9 provincias), sobre todo por sequías; por falta de trabajo, o por pobreza (en 16 provincias); y también por falta de inmigración de jornaleros del campo, especialmente en las provincias mediterráneas, lo que se vincula con la nueva fecha censal (25-XII-1860), que coincide con inactividad de buena parte de los calendarios agrícolas, sobre todo respecto al 21 de mayo de 1857.

La emigración invernal hacia Andalucía para atender la recogida y molienda de la aceituna, tiene un radio de atracción de jornaleros que afecta a censos demográficos municipales -según las «notas» publicadas en el censo de 1860- de las provincias de Albacete, Castellón, Santander, Soria y, también, de la propia Granada. No obstante, como se ha indicado, la causa de emigración más repetida por los ayuntamientos es la falta de trabajo y la pobreza.

6 Por otra parte, la Junta General de Estadística, consciente de las deficiencias que presentaban las estadísticas provinciales del movimiento natural de España -bautismos, matrimonios, defunciones- en los primeros años que se publican estos datos (Memoria de los años 1858, 1859, 1860, 1861 y 1862), también solicitó a sus secciones provinciales que en sus memorias sobre el movimiento natural indicaran las causas de las variaciones interanuales.

Así, pues, la indicada metodología explicativa de las variaciones censales negativas de los municipios en 1860, también la utiliza la Junta General de Estadística en la Memoria sobre el movimiento de la población de España (aunque esta Memoria sólo incluye el movimiento natural, y no el saldo migratorio, pues «la emigración no [está] consignada por completo en ningún documento»-p. 7-), referida a los años 1858 a 1862 . No obstante, en esta publicación de 1863, las causas de las variaciones interanuales en bautismos, matrimonios y defunciones, sólo se especifican si la variación provincial excede -positiva o negativamente- en un $10 \%$ ó más en 1859 respecto a 1858 , y en 1860 respecto a 1858 y 1859. En cualquier caso, las notas explicativas que remiten las secciones provinciales de la Junta General, se caracterizan por su carácter incompleto (Memoria, p.51); así, las memorias provinciales sólo aportan el $26 \%$ de los hechos explicativos que se les solicitan, «Pero incompletos y todo, las memorias de las secciones [provinciales] arrojan gran luz sobre el valor que debe atribuirse a los registros [de la Iglesia sobre el movimiento natural], y demuestran la necesidad de reformar este importante servicio». 
La emigración por causas ganaderas está referida a la trashumancia invernal, y se explicita para municipios de 10 provincias de la mitad norte de la península, aunque también el interior montañoso de Castellón (fig. 2).

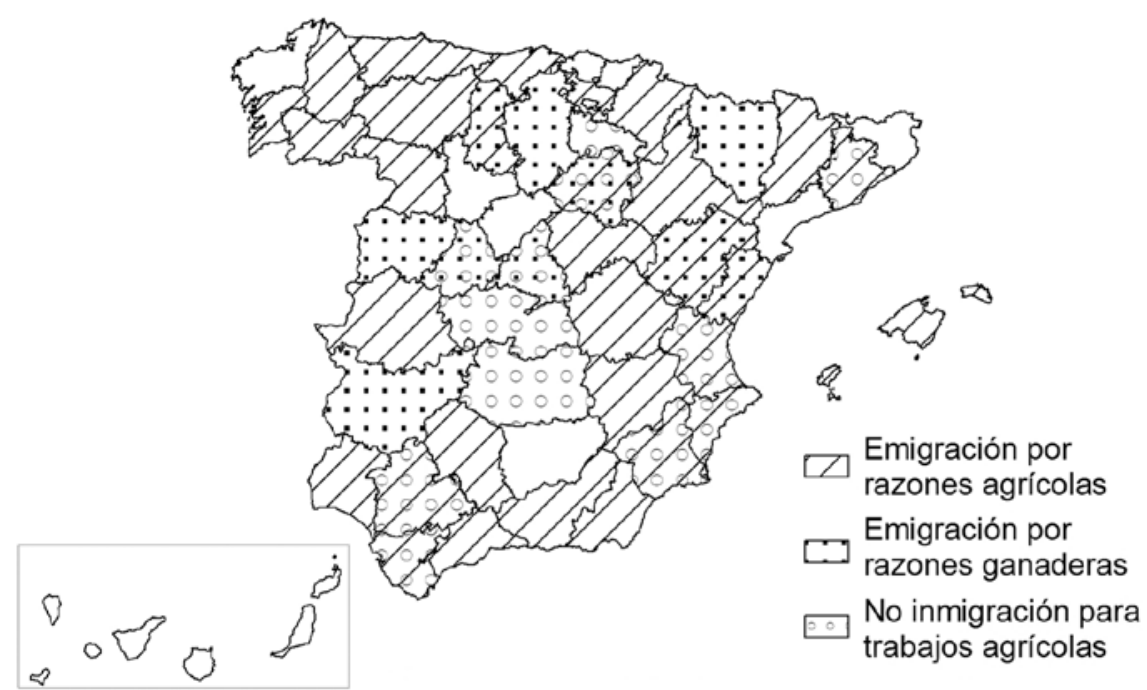

Fuente: Junta General de Estadística: Censo de la población de España de 1860.

El minifundismo agrario, que sin duda padece un alto número de propietarios en España -éstos son 1,5 millones según el censo de población de 1860- y de arrendatarios -510.468-, también hay que contabilizarlo como causa muy importante de emigración, tanto de la interior como de la exterior (Eiras Roel, 1991; Gozálvez, 1977; González Portilla et al., 1987), aunque en las «notas» del censo de 1860 sólo se explicita como causa de emigración para municipios de la provincia de Alava. Eiras Roel (1989) señala el minifundismo y la presión demográfica sobre la tierra, como causa principal para explicar la emigración hacia América más intensa en Galicia y en Canarias durante el siglo XIX.

Finalmente la filoxera, «enfermedad de la vid», también se cita como causa del descenso de habitantes en 1860 en municipios de la provincia de Barcelona, aunque también en Lugo la «emigración constante y general que se observa en todos los pueblos de Galicia, y especialmente en los vinícolas, por efecto de las malas cosechas».

En conclusión, como se cartografía en la fig. 2, la disminución de censos municipales en 1860 por causas relacionadas con el sector agrario afecta a casi todas las provincias; en la mayoría de ellas se trata de migraciones interiores de temporada, cuya generalización está relacionada con el altísimo volumen de jornaleros del campo - 2.354.000-, que suponen más de la mitad de los activos de todo el sector primario (éste acumula el $63 \%$ de la población activa de España), e igualmente con el minifundismo agrario. En consecuencia, la falta de 
trabajo y la pobreza, derivadas de la estructura productiva del sector agrario, y de la escasez e irregularidad pluviométrica, alimentan las migraciones tanto interiores como exteriores, sobre todo hacia América (desde Canarias y desde la franja litoral del norte de la península) y hacia Argelia desde el sureste peninsular.

b) Las obras públicas provocan descenso municipal de habitantes en 1860 bien por paralización de esas obras o bien por haberlas finalizado. Con la excepción de Córdoba, todas las provincias con municipios en esta situación, se localizan en el cuadrilatero NE de la península (fig. 3), y están referidas fundamentalmente a la conclusión de obras de ferrocarril. También se cita la paralización de las obras del Canal de Isabel II (Madrid), lo que provoca «...ausencia de los trabajadores transeúntes y cuadrillas de presidiarios que se ocupaban en las obras de las vías férreas de Zaragoza y del Norte, y en las del Canal de Isabel II». En el caso de Tarragona, los «Ayuntamientos con menos población que en 1857, por la ausencia de trabajadores forasteros y muchos del país que se ocupaban en las obras de la canalización del Ebro, las cuales estaban paralizadas al verificarse el presente recuento [1860],..».

Otras actividades del sector secundario a las que se considera responsables de disminuciones censales municipales, son: emigración por decadencia de la minería en las provincias de Huelva (que en 1860 censaba un total de 2.175 mineros) y de Murcia (con 2.694, de un total nacional de 23.358 mineros); por decadencia de las fábricas de paños de Segovia; en Gerona se citan como causa de disminuciones censales, además de la emigración a Ultramar, «...más especialmente a Barcelona, con objeto de ocuparse en los establecimientos industriales y en la construcción de las vías férreas»; la crisis en la industria algodonera de Barcelona también

Figura 3

CAUSAS DE DISMINUCIÓN MUNICIPAL DE HABITANTES ENTRE 1857 Y 1860: EMIGRACIÓN POR FIN/PARALIZACIÓN DE OBRAS PÚBLICAS

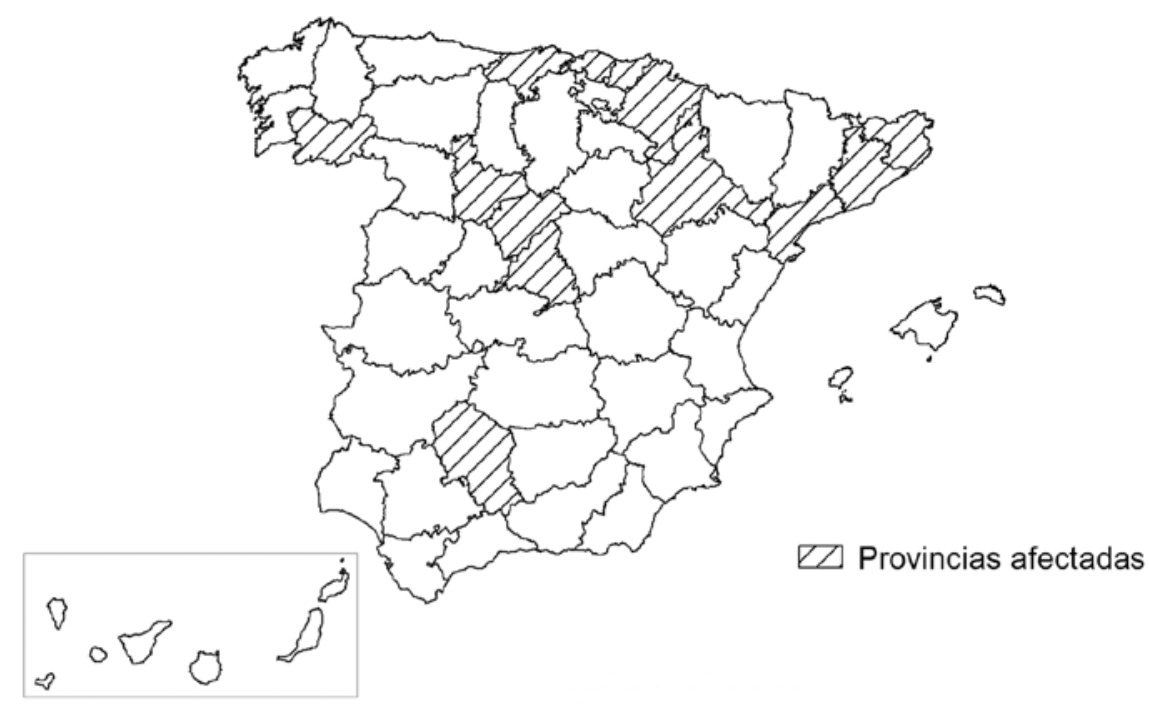

Fuente: Junta General de Estadística: Censo de la población de España de 1860. 
provoca disminuciones de población en determinados municipios de esta provincia: «cambio de domicilio de muchas familias por efecto de la paralización de la industria algodonera».

c) El exceso de defunciones sobre nacimientos como causa de disminuciones censales municipales se cita en 14 provincias (fig. 4A). Esta mortalidad casi siempre está vinculada a enfermedades epidémicas, sobre todo cólera, pero también viruela y sarampión, aunque en el caso de Cáceres la «nota» del censo cita el «excesivo número de defunciones... en el año 1858, a causa del hambre experimentada en el mismo año».

Las mayores epidemias de cólera en España están centradas en los años 1833-34, 185455, 1865 y 1885 (Feo Parrondo, 2005), aunque esta epidemia también se padece en numerosos brotes menores, como ocurre, según las notas del censo de 1860, durante los años 1858, 1859 y sobre todo en 1860 .

Las provincias que padecen brotes de cólera entre 1857 y 1860 no se limitan a las 14 señaladas en las «notas» del censo de población. En efecto, los informes sobre movimiento natural que envían a la Junta General de Estadística sus secciones provinciales (ver nota 6), también señalan las mismas enfermedades epidémicas -cólera, viruela, sarampión- para explicar variaciones interanuales durante el periodo 1858-1860 iguales o superiores al 10\% en cada uno de los componentes del movimiento natural de las provincias -bautismos, matrimonios, defunciones- (fig. 4B).

d) La emigración exterior como causa de disminución censal municipal en 1860 respecto a 1857, es citada en el censo de población de 1860 para municipios de 12 provincias (fig. 5), las que se extienden por toda la franja septentrional de la península y Almería, aunque a éstas hay que añadir Canarias, única provincia que no da información para esta «nota» del censo, ni tampoco para otras cuestiones similares solicitadas por la Junta General de Estadística. En cualquier caso, la importancia de la emigración transoceánica canaria queda patente en el acusado descenso de su sex ratio entre la población que en 1860 tenía 16 y más años de edad: 71,8 varones de 16 a 50 años de edad por 100 mujeres, frente a su sex ratio normal en el tramo de cero a 10 años de edad, 104,8 varones por 100 mujeres. Así, según esta estructura por sexos, la intensidad de la emigración joven masculina canaria es similar a la que registran Pontevedra (65,8 varones por 100 mujeres), Coruña $(71,5)$ y Oviedo $(71,3)$, y superior a la de Lugo $(79,4)$, Orense $(82,4)$, Santander $(83,3)$ y Vizcaya $(85,9)$. En el caso de Almería, el principal destino de su emigración (sex ratio de 87,3 entre 16 y 50 años de edad) es la Argelia colonial francesa, flujo que también afectaba a las provincias vecinas de Alicante $(94,8)$ y Murcia $(98,8)$, aunque en estas dos provincias la emigración tenga menores efectos demográficos, sin duda porque buena parte de esta emigración es temporal ${ }^{7}$.

7 En efecto, para el caso del extenso, poblado y agrícola término municipal de Elche (Alicante)(Gozálvez, 1977), la emigración a Argelia ya era muy cuantiosa desde los años 1840 (Gozálvez, 1976:231), igual que para otras áreas del sureste peninsular (Bonmatí, 1992; Gozálvez, 2011). La sequía aparece siempre como el motor oficial de las emigraciones a Argelia en las indicadas provincias del sureste peninsular, facilitadas por la proximidad de los emigrantes a los puertos de la costa mediterránea española, por la cercanía de las costas argelinas, por el bajo coste económico del trayecto marítimo y por la relativa abundancia de embarcaciones, tanto para los traslados legales como para los irregulares (entre éstos, para eludir el servicio militar); los numerosos puertos pesqueros en las costas del sureste español facilitaban mucho esta emigración para los jóvenes que se acercaban a la edad del servicio militar (Gozálvez, 1997). Asimismo son determinantes para emprender estas emigraciones, con frecuencia de tipo «golondrina» o de temporada agrícola, la analogía de los paisajes agrarios en el SE de España y en Argelia, el minifundismo y las elevadas densidades agrarias en relación a la baja productividad y, como se ha indicado, la masa de jornaleros agrícolas. 
Figura 4

CAUSAS DE DISMINUCIÓN MUNICIPAL DE HABITANTES ENTRE 1857 Y 1860 A: POR EXCESO DE DEFUNCIONES SOBRE NACIMIENTOS. B: POR MORTALIDAD EPIDÉMICA

A:

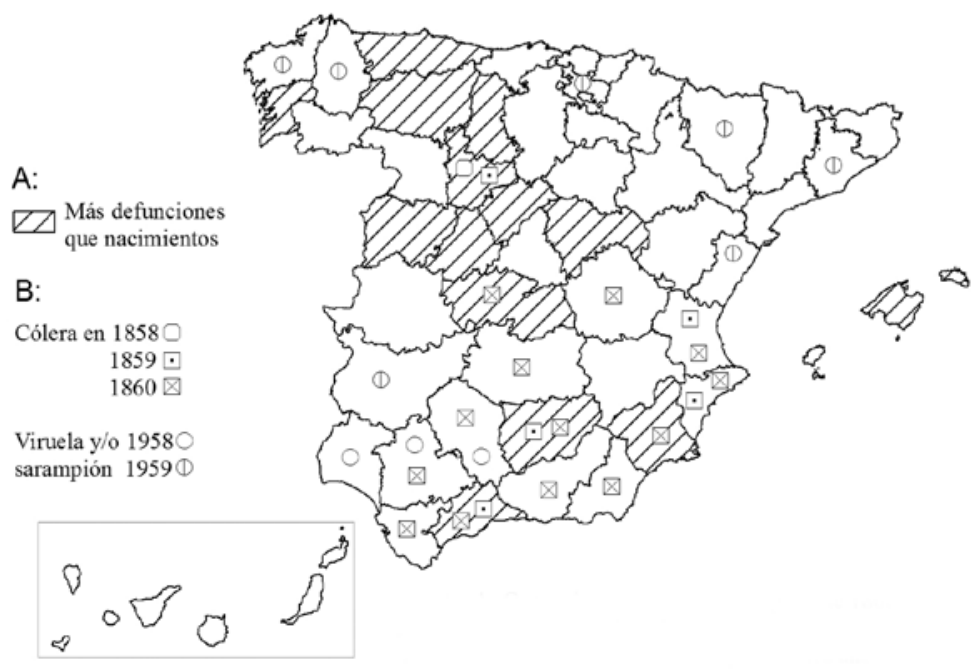

Fuente: A. Censo de la población de España de 1860. B: Junta General de Estadística del Reino: Memoria sobre el movimiento de la población de España en los años 1858, 1859, 1860 y 1861.

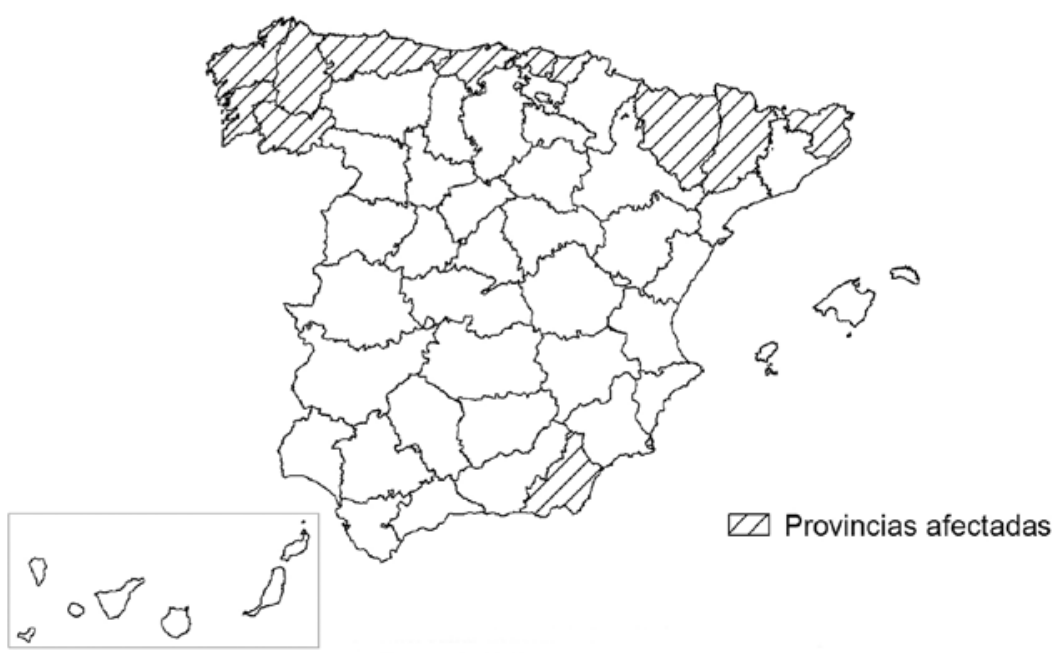

Fuente: Junta General de Estadística: Censo de la población de España de 1860. 
El principal destino de la emigración exterior de las provincias del norte peninsular es América hispana o «Ultramar», según lo especifican las notas del censo de 1860 para Coruña, Pontevedra, Lugo, Orense, Santander, Guipúzcoa y Gerona. Además, el censo también señala los destinos de Portugal para los emigrantes de Coruña y Pontevedra, y de Francia para Coruña, Pontevedra, Huesca y Lérida, aunque para las dos últimas provincias se trata fundamentalmente de emigración invernal.

La acusada emigración de varones jóvenes hacia América tiene efectos negativos no sólo en los censos demográficos de muchos municipios, sino que también modifica gravemente la estructura demográfica del conjunto de las provincias, al reducir fuertemente el número de varones jóvenes -a partir del grupo de 16-19 años de edad- respecto a las mujeres de la misma edad; esta carencia de varones incide negativamente en el mercado matrimonial y en el aumento de la natalidad «ilegítima» (Martín Ruíz; Díaz Rodríguez, 1985).

En efecto, según los datos sobre bautismos proporcionados por los párrocos en 1860 a la Junta General de Estadística (Anuario Estadístico de España, 1862-1863), los bautizados «ilegítimos» -nacidos fuera de matrimonio legalizado- alcanzan tasas provinciales -sobre el total de bautizados- del 20,4\% en Canarias, 18,4\% en Lugo, 15,0\% en Coruña, $14,0 \%$ en Pontevedra, 9,8\% en Orense o 6,5\% en Oviedo mientras la media de España se situaba en el 5,6\%, y en 34 de las 49 provincias esta tasa oscilaba entre 1,4\% y 4,9\%. Hay pues clara relación entre las provincias con más emigración masculina de larga duración y aumento de la natalidad ilegítima, sin duda a consecuencia de desajustes en el mercado matrimonial, aunque la emigración de varones previsiblemente no sea causa única de los hijos habidos fuera de matrimonio. Es decir, las altas tasas de natalidad ilegítima señaladas, también deben estar propiciadas por otras causas socioeconómicas negativas, como son unas altísimas tasas de analfabetismo y de severa pobreza en las mujeres, así como absoluta carencia laboral que propiciara la independencia femenina, tal como se deduce de la información censal (p.e. en la provincia de Lugo las mujeres alfabetizadas de 11 y más años de edad son el 4,0\%, los pobres de solemnidad censados son el 31,1 por $1.000-16,8 \%$ en España-, mientras la tasa de activos en el sector secundario es del $6,9 \%-17,4 \%$ en España-). De hecho, en Santander, con tasa de sex ratio de $83,3 \%$, pero con mejora sustancial de los indicadores socioeconómicos (cuadro 1), la tasa de bautizados ilegítimos es sólo de $4,0 \%$ y de $2,4 \%$ en Vizcaya. Por otra parte, las tasas de natalidad ilegítima, en opinión de la Junta General de Estadística debían ser más elevadas de lo que indican los bautizados, debido, sobre todo, a los nacidos muertos y a los fallecidos antes de su bautismo, que la Junta estima en un 7\% sobre el total de nacidos (Memoria sobre el movimiento de la población de España en los años 1858 ... y 1861, p. 52).

Los gráficos de sex ratio de las principales provincias de emigración exterior en 1860 (fig. 6), permiten diferenciar al menos cuatro situaciones diferentes en la estructura por sexos y edad según sea la intensidad de la emigración, su antigüedad y los retornos de los emigrantes. No obstante, todos ellos tienen una parte de comportamiento común: el inicio de la emigración intensa se produce entre los varones del grupo de edad de 16 a 19 años, tal como lo evidencia el brusco descenso de la sex ratio, sobre todo durante la primera mitad de dicho grupo etario (Eiras Roel, 1991). La entrada en la edad laboral, la proximidad de la incorporación al servicio militar (18 años de edad), la alta presión demográfica en relación a los recursos económicos en las zonas de emigración (minifundismo agrario), 
Figura 6

CURVAS DE «SEX RATIO» (NÚMERO DE VARONES POR 100 MUJERES) SEGÚN EDAD, EN 1860 TOTAL DE ESPAÑA Y PROVINCIAS MÁS EMIGRATORIAS
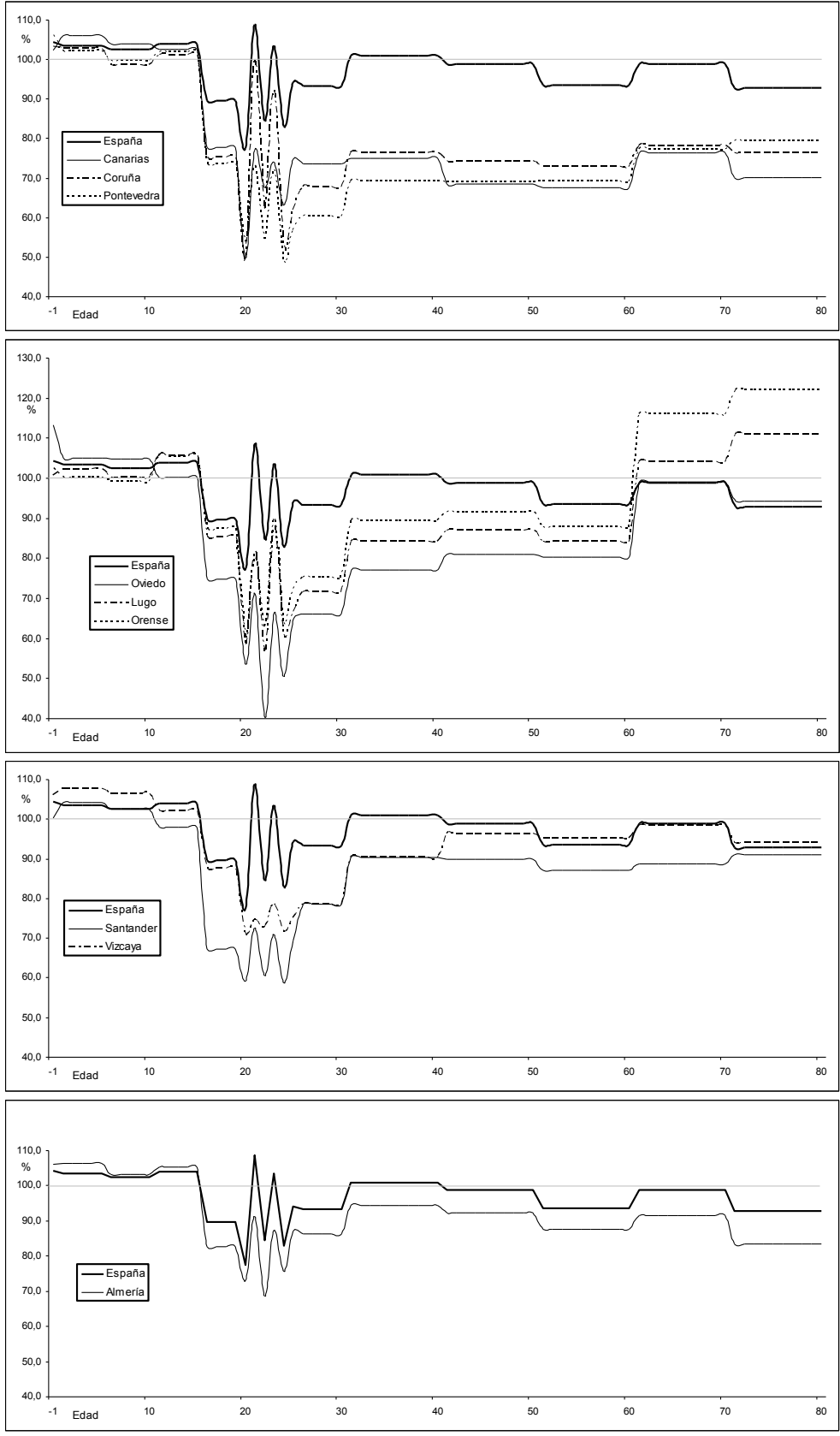

Fuente: Junta General de Estadística: Censo de la población de España de 1860. 
altísimas tasas de jornaleros dentro de un sector agrario de baja productividad, la proximidad de los emigrantes a los puertos marítimos españoles, junto a otras causas sociales y económicas, son los detonantes internos más importantes y generalizados de tales éxodos de varones jóvenes (Palazón, 1995a; 1995b).

En efecto, de acuerdo con los gráficos (fig. 6) y estadísticas censales aportados (cuadro 1), en 1860 podemos diferenciar cuatro situaciones emigratorias:

1) Canarias, Pontevedra y Coruña, son las provincias que ofrecen las tasas de sex ratio más menguadas, en torno a 70 varones por cada 100 mujeres en el grupo de 16 a 50 años de edad; su déficit de varones se prolonga hasta el límite de la edad activa, lo que denuncia una emigración de mayor antigüedad en los flujos de estas tres provincias, y también menores retornos de emigrantes adultos-viejos. Según las estadísticas demográficas y socioeconómicas aportadas (fig. 6, cuadro 1), Pontevedra da la emigración más intensa: su densidad rural es de 98 habit./ $\mathrm{Km}^{2}$-España 31-, mientras en su capital sólo concentra el $1,5 \%$ de la población provincial; el $80 \%$ de sus activos trabaja en el sector agrario, mientras la alternativa industrial apenas si existe aquí - $11 \%$ de sus activos-; la tasa de alfabetización femenina es de 4,4\%, mientras su índice de pobreza es, según el Censo de 1860, el más alto de España, con 32,3 pobres de solemnidad por 1.000 habitantes; a consecuencia de la mayor sangría de población joven emigrada, Pontevedra también alcanza los indicadores de vejez más altos de España: 27,2 años de edad mediana y 7,7\% de la población con 61 años y más (cuadro 1).

2) El grupo de las provincias de Oviedo, Lugo y Orense padecen indicadores socioeconómicos también muy favorecedores para la emigración, similares a los del grupo anterior, e incluso la situación se agrava en la Galicia interior con el descenso de las alternativas laborales en el sector secundario (cuadro 1). La mayor intensidad de la emigración en Oviedo -tasa más baja de sex ratio- sin duda se debe a su carácter litoral con puertos marítimos. El carácter distintivo de las provincias de este grupo respecto al grupo primero, está en la recuperación «temprana» de la sex ratio (fig. 6) entre los que tienen más de 30 años de edad, sobre todo en la Galicia interior, lo que parece indicar que en este grupo la emigración masiva hacia América se inicia probablemente más tarde; la recuperación de la sex ratio por un mayor número de retornos de emigrantes no parece causa creíble dadas las mayores dificultades económicas en las provincias de Galicia interior (cuadro 1).

En cualquier caso, las seis provincias emigratorias que forman los dos grupos indicados, presentan muchos indicadores comunes, sobre todo los que denuncian sus deficientes condiciones socioeconómicas, déficit muy alto de varones entre 16 y 50 años de edad, y mayor envejecimiento.

3) Santander y Vizcaya muestran una sex ratio en 1860 que responde a una emigración exterior menos intensa en las edades jóvenes, al mismo tiempo que el número de varones se recupera ostensiblemente por encima de los 35 años de edad; así, la emigración más reciente y menos intensa también podría estar acompañada por retornos tempranos. Como explicación de este comportamiento emigratorio «reducido», en Santander y Vizcaya se pueden destacar, en relación a los grupos de provincias anteriores, las mejores alternativas económicas que se ofertan en el sector secundario, la fuerte reducción de sus tasas de pobreza, o el ostensible aumento de las tasas de mujeres alfabetizadas (Cuadro 1). 


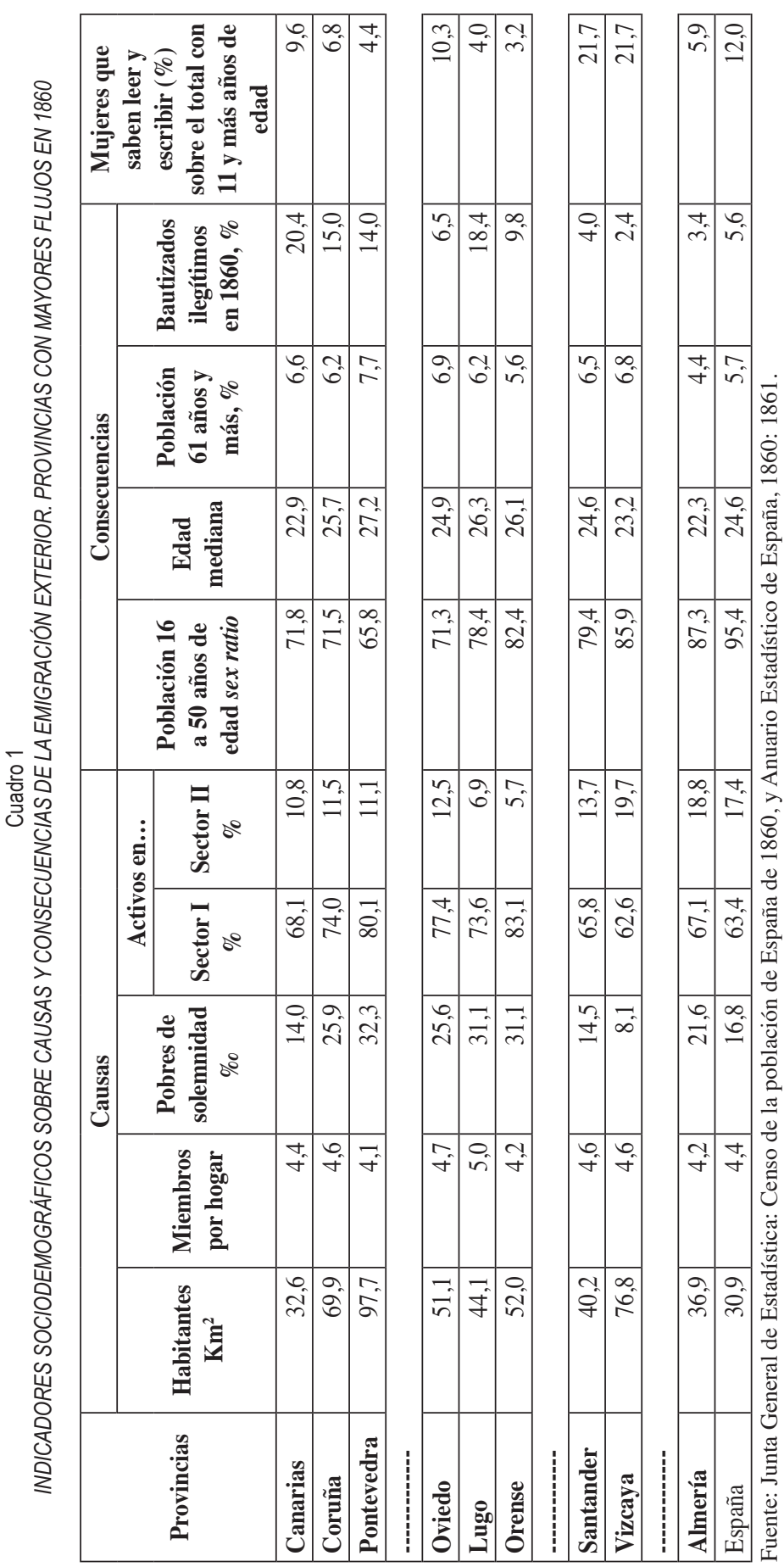


4) Finalmente, Almería es la provincia del SE peninsular con mayor emigración hacia la Argelia colonial (Bonmatí, 1992), aunque en relación a las provincias del norte peninsular disminuye considerablemente su tasa de emigración masculina de larga duración, pues, como se indicó, la cercanía de Argelia y la facilidad para los transportes entre las costas de ambos países, hacen que esta emigración sea en buena medida de temporada.

En los nueve casos de sex ratio estudiados (fig. 6), las distintas intensidades de los «dientes de sierra» de las curvas entre 20 y 25 años de edad, reflejan, por una parte, las diferencias provinciales en las tasas de alfabetización de las mujeres, y por otra las desigualdades de alfabetización entre hombres y mujeres; el mayor analfabetismo de las mujeres se traduce en un mayor redondeo etario declarado respecto a los varones, siempre a favor de las edades terminadas en cero, en 5 y en número par, y por este orden.

\section{INFRAESTRUCTURAS HUMANAS PARA LA ENSEÑANZA PRIMARIA. NIVELES DE FRECUEN- TACIÓN ESCOLAR Y DE ALFABETIZACIÓN. LA DISCRIMINACIÓN EDUCATIVA FEMENINA}

El censo de población de 1860 incorpora, como novedad trascendente, información sobre la población que asistía a centros de enseñanza, sobre el profesorado y sobre el nivel de alfabetización. La estructuración de esta información en el censo responde, en líneas generales, a la recientemente aprobada «Ley de Instrucción Pública» de 9 de septiembre de 1857, conocida como «Ley Moyano», por su promotor Claudio Moyano, Ministro de Fomento.

El problema educativo más acuciante que tenía España en aquel momento era, sin duda, las elevadas tasas de analfabetismo, por lo que la información censal más completa relativa a la educación fue la referida al nivel de alfabetización y a su «fuente», esto es los niños que asistían a las escuelas primarias y los maestros que se ocupaban de éstas. Estos tres epígrafes - población alfabetizada, niños que asistían a la escuela primaria y sus maestros- se ofrecen por sexos, información que significativamente no se incluye en las estadísticas sobre estudiantes y profesores de enseñanzas secundaria y universitaria, de lo que se concluye el predominio absoluto de la población masculina entre alumnos y profesores de estos niveles; por otra parte, esta masculinización era la consecuencia lógica de los deplorables niveles que sufría el sexo femenino en lo que concierne a su instrucción primaria, es decir niñas que asistían a las escuelas y a la dotación de maestras, tal como en parte se refleja en los datos nacionales ofrecidos en el cuadro 2 .

La información sobre alfabetización se publica a escala provincial y municipal, dentro del apartado censal dedicado a la estructura demográfica de cada provincia. Las rúbricas con esta información, por sexos, son: «sabe leer y escribir» (que es la que utilizaremos en este estudio), «sabe leer y no escribir»y «no sabe leer». Ninguna de las informaciones referidas a la educación se vincula directamente a la edad de esta población, por lo que los análisis sobre estas variables quedan mermados. No obstante, esta carencia, a efectos de calcular tasas de alfabetización, puede, en parte, ser suplida mediante la comparación de la población que declara saber leer y escribir, con los grupos por sexos y con edades de 11 y más años, que también publica el censo a escalas provincial y municipal. En concreto, para el conjunto de España declaran que saber leer y escribir 2.408.620 varones y 715.790 mujeres, es decir estarían alfabetizados el $42 \%$ de los varones de 11 y más años de edad, por sólo el $12 \%$ de las mujeres. Como veremos, además de las diferencias por sexo en la alfabetización, también 
Cuadro 2.

ESPAÑA, 1860. TOTALES DE POBLACIÓN ALFABETIZADA, ALUMNOS QUE ASISTEN A CENTROS DE ENSEÑANZA Y PROFESORADO

a) Población alfabetizada: varones 2.408 .620 , tasa* $41,7 \%$; mujeres 715.790 , tasa* $12,0 \%$

b) Alumnos:

- Niños que van a la escuela:

667.100

- Niñas que van a la escuela: $\quad 434.478$

- Colegiales de primera y segunda enseñanza

- Estudiantes de segunda enseñanza 36.146

- Estudiantes de estudios superiores 11.375

- Estudiantes para carreras especiales 7.029

18.404

c) Profesorado:

- Maestros de primera enseñanza

Niños escolarizados/maestro: 43

- Maestras de primera enseñanza

- Maestros de enseñanza particular 1.396

Niñas escolarizadas/maestra: 56

- Catedráticos y profesores

Habitantes/maestra: 2.010

* Tasa: saben leer y escribir respecto a la población de su sexo con 11 y más años de edad.

Fuente: Junta General de Estadística: Censo de la población de España de 1860.

existen acusados contrastes territoriales -a escala provincial- y de hábitat, es decir entre población urbana -la residente en capitales de provincia- y población rural o residente en el resto de la provincia. Así, en las capitales -que censan el 11,8\% del total de la población de España- ambos sexos elevan mucho sus tasas medias de alfabetizados, al 58,5\% los varones y al 30,2\% las mujeres; la población residente en hábitat rural ofrece tasas de alfabetización sólo ligeramente inferiores a la media del total nacional, dado el escaso peso de las poblaciones capitalinas: los varones rurales rebajan sus tasas al 39\% y las mujeres al $9 \%$. Además, estas fortísimas desigualdades de alfabetización entre hombres y mujeres se agrandan entre las 49 provincias españolas, como veremos.

En 1860, según la nueva información censal sobre estructura de empleo y del nivel de alfabetización, España es un país profundamente rural y agrario, y con tasas de analfabetismo muy elevadas, sobre todo entre las mujeres. Por ello, la alfabetización es una meta de la mayor trascendencia en la educación y, por consiguiente, para la transformación económica y social del país, que debería producirse a corto plazo; en consecuencia el problema de la alfabetización debe abordarse empezando por los factores que conducen a ella, es decir los docentes de enseñanza primaria y la escolarización infantil.

Las informaciones sobre alumnos y profesores se publican como parte de la «Clasificación de los habitantes por profesiones, artes y oficios»; el censo distingue seis apartados o «profesiones», dos por cada nivel de enseñanza -primaria, secundaria, superior-, con los enunciados que se recogen en el cuadro 2. La desagregación espacial es, en este caso, las provincias y partidos judiciales.

La discriminación femenina en la escolarización e instrucción elemental, como es la alfabetización, queda bien patente tanto en el censo de la población de España de 1860, como en la Ley de Instrucción Pública de 9 de septiembre de 1857. La erradicación de esta discrimi- 
nación femenina quedaba todavía lejos de las prioridades de la sociedad y de los gobernantes. En efecto, los maestros varones de primera enseñanza eran, según el Censo, exactamente el doble que las maestras -15.536 frente a 7.789 (cuadro 2)-, mientras la enseñanza primaria quedaba sancionada como obligatoria por la Ley Moyano para todos los niños de ambos sexos entre 6 y 9 años de edad (art. 7) ${ }^{8}$; así, la citada disparidad numérica entre maestros y maestras difícilmente podría garantizar la igualdad de escolarización y de aprendizaje entre niños y niñas. En concreto, la tasa de escolarización o frecuentación escolar calculada con el número de niños que según el censo «concurrían» a la escuela, en proporción a la población infantil de 6 a 15 años de edad, alcanzaba, a escala nacional, al 41\% de los niños por sólo el $27 \%$ de las niñas; esto suponía, según los datos del censo, una presencia escolar media de 43 niños por maestro frente a 53 niñas por maestra.

Pese a la obligatoriedad legal de la escolarización infantil entre 6 y 9 años de edad, y a la infradotación de maestras, que automáticamente les producía sobrecarga laboral, éstas sufrían discriminación económica en su sueldo oficial, pues según la Ley Moyano (art. 194), las maestras cobrarían un tercio menos que sus colegas masculinos. Además, los rendimientos escolares podrían verse afectados negativamente no sólo por los bajos salarios de los maestros -que, según la Ley Moyano, oscilaban entre 9.000 reales/año en Madrid, y 2.500 reales para los maestros que ejercían en pueblos rurales entre 500 y 1.000 habitantes-, sino por el atraso de hasta seis meses que -en casos estudiados- podían sufrir en su percepción (Montero, 2009). La discriminación escolar también la podían sufrir las niñas en las «escuelas incompletas», que son las que no impartían todas las asignaturas especificadas en el plan de estudios (art. 3) y, sobre todo, las que carecían de maestro con titulación oficial (art. 102, 181, 189) ${ }^{9}$, pues estas escuelas incompletas afectaban más a las niñas que a los niños (art. 100).

\section{III.1. LA FRECUENTACIÓN ESCOLAR}

Los «niños que concurren a la escuela» censados en 1860 , debe entenderse como frecuentación escolar, pues los datos censales no informan sobre la regularidad de la asistencia al aula, ni sobre la duración de los estudios, ni tampoco sobre las edades de los escolares. No obstante, la Ley de Instrucción Pública de 1857 sí incluye la obligatoriedad de la escolarización para toda la población infantil entre 6 y 9 años de edad, es decir para 843.812 niños censados y para 823.286 niñas.

Para valorar la frecuentación escolar utilizamos las estadísticas censales referidas a los maestros de «primera enseñanza», por sexos -15.536 maestros y 7.789 maestras-, los niños que asisten a la escuela, por sexos -667.100 niños y 434.478 niñas-, así como toda la pobla-

8 El incumplimiento de la escolarización obligatoria (art. 7 de la Ley de Instrucción Pública de 1857) era castigado con multa económica de 2 a 20 reales (art. 8). La ley también contemplaba la gratuidad relativa de la enseñanza primaria en las escuelas públicas, es decir quedaban exentos de pago en este nivel de enseñanza los padres que justificasen carencia de medios económicos; el aval con esta finalidad lo proporcionaba un certificado del párroco, con el visto bueno del alcalde (art. 9).

9 «En todo pueblo de 500 almas habrá necesariamente una Escuela pública elemental de niños, y otra, aunque sea incompleta, de niñas. Las incompletas de niños sólo se consentirán en pueblos de menor vecindario» (art. 100).

«Las escuelas incompletas y las de temporadas se desempeñarán por adjuntos o pasantes, bajo la dirección y vigilancia del Maestro de la Escuela completa más próxima» (art. 102). 
Figura $7 \mathrm{~A}$

ESPAÑA, 1860. NIÑOS QUE CONCURREN A LA ESCUELA (\%) SOBRE POBLACIÓN MASCULINADE 6 A 15 AÑNOS DE EDAD

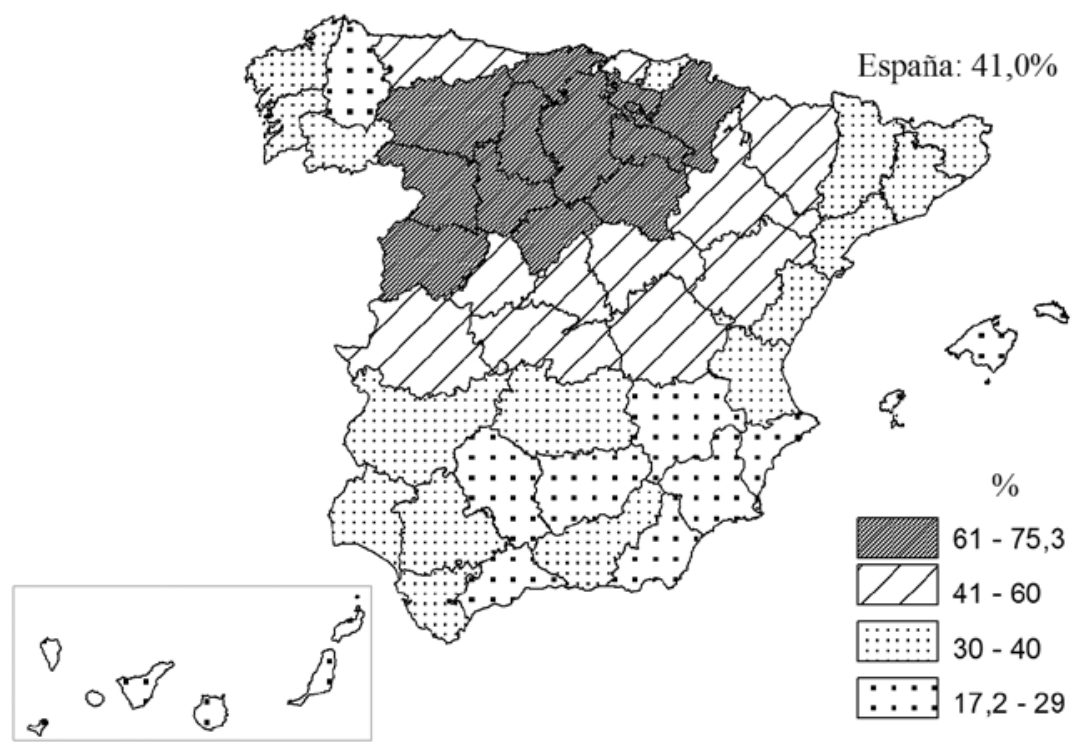

Figura 7B

ESPAÑA, 1860. NIÑAS QUE CONCURREN A LA ESCUELA (\%) SOBRE POBLACIÓN FEMENINA DE 6 A 15 AÑOS DE EDAD

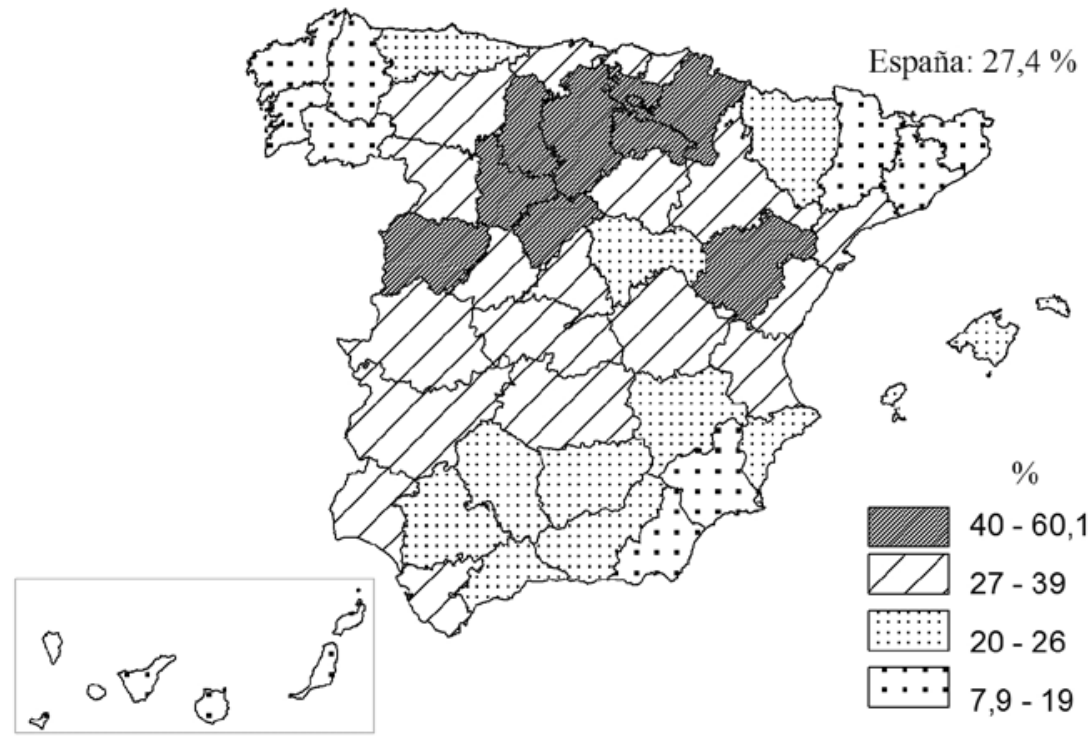

Fuente: Junta General de Estadística: Censo de la población de España de 1860. 
Cuadro 3

AÑO 1860. PROPORCIONES MAYORES Y MENORES ENTRE LAS PROVINCIAS DE ESPAÑA, DE LOS «NIÑOS QUE CONCURREN A LA ESCUELA» RESPECTO A LOS QUE TIENEN ENTRE 6 Y 15 AÑOS DE EDAD, E INDICADORES EXPLICATIVOS

\begin{tabular}{|c|c|c|c|c|c|c|c|c|}
\hline \multirow{3}{*}{ Provincia } & \multirow{3}{*}{$\begin{array}{c}\text { Niños } \\
\%\end{array}$} & \multirow{3}{*}{$\begin{array}{c}\text { Niñas } \\
\%\end{array}$} & \multirow{3}{*}{$\begin{array}{c}\text { Diferencia } \\
\%\end{array}$} & \multicolumn{5}{|c|}{ Indicadores explicativos } \\
\hline & & & & \multicolumn{2}{|c|}{$\begin{array}{c}\text { Número de } \\
\text { habitantes por... }\end{array}$} & \multirow{2}{*}{$\begin{array}{c}\text { Clero secular } \\
\text { por } 1.000 \\
\text { habitantes }\end{array}$} & \multirow{2}{*}{$\begin{array}{c}\% \text { de jornaleros } \\
\text { del campo } \\
\text { sobre total de } \\
\text { empleo en sector } \\
\text { primario }\end{array}$} & \multirow{2}{*}{$\begin{array}{l}\% \text { varones } \\
\text { alfabetizados }\end{array}$} \\
\hline & & & & Maestro & Maestra & & & \\
\hline España & 41,0 & 27,4 & -33 & 1.008 & 2.010 & 2,7 & 54,4 & 41,7 \\
\hline \multicolumn{9}{|c|}{ 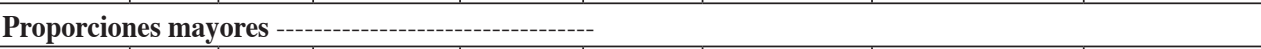 } \\
\hline Álava & 75,3 & 61,6 & -18 & \begin{tabular}{r|}
350 \\
\end{tabular} & 1.959 & 6,8 & 42,6 & 75,4 \\
\hline Burgos & 73,1 & 43,8 & -40 & 426 & 4.378 & 4,5 & 40,6 & 74,8 \\
\hline León & 71,6 & 27,9 & -61 & 399 & 4.003 & 4,6 & 46,7 & 65,7 \\
\hline Segovia & 69,2 & 54,5 & -21 & 457 & 1.540 & 3,0 & 31,3 & 71,2 \\
\hline Palencia & 68,7 & 42,2 & -39 & 647 & 2.619 & 4,6 & 47,2 & 74,1 \\
\hline Soria & 67,9 & 35,9 & -47 & 329 & 3.561 & 3,9 & 24,8 & 75,4 \\
\hline Santander & 67,1 & 34,2 & -49 & 738 & 2.844 & 3,8 & 42,1 & 80,1 \\
\hline Logroño & 64,5 & 49,6 & -23 & 674 & 1.805 & 4,3 & 50,9 & 63,9 \\
\hline \multicolumn{9}{|c|}{--------------------------------- } \\
\hline \multicolumn{9}{|c|}{ Proporciones menores } \\
\hline Málaga & 27,2 & 21,4 & -21 & 2.326 & 2.302 & 1,5 & 52,3 & 24,5 \\
\hline Baleares & 26,5 & 25,6 & -3 & 2.108 & 1.542 & 3,7 & 63,5 & 26,6 \\
\hline Albacete & 25,8 & 22,3 & -14 & 1.808 & 1.451 & 1,3 & 58,7 & 27,1 \\
\hline Alicante & 25,3 & 23,9 & -6 & 1.634 & 1.544 & 1,8 & 47,9 & 21,7 \\
\hline Murcia & 23,3 & 15,7 & -33 & 2.163 & 2.945 & 1,6 & 62,2 & 25,4 \\
\hline Lugo & 21,9 & 7,9 & -64 & 2.845 & 12.357 & 3,2 & 41,1 & 44,3 \\
\hline Almería & 19,1 & 12,0 & -37 & 1.984 & 1.866 & 1,2 & 49,5 & 22,2 \\
\hline Canarias & 17,2 & 10,4 & -40 & 2.236 & 3.823 & 1,1 & 57,3 & 19,4 \\
\hline
\end{tabular}

Fuente: Junta General de Estadística: Censo de la población de España de 1860.

ción infantil censada entre 6 y 15 años de edad -1.639.106 niños y 1.588 .312 niñas- lo que nos proporcionaría una aproximación a las tasas de frecuentación escolar utilizadas en este estudio.

Igual que sucede con otras variables educativas, las tasas de frecuentación escolar en España muestran fuerte desigualdad entre sexos: $41 \%$ para los niños, por sólo $27 \%$ entre las niñas; estas diferencias responden tanto a la muy inferior dotación de maestras respecto a los maestros varones, como a la menor «rentabilidad» de la inversión en la escolarización de las niñas, tal como era percibida en el seno de la mentalidad familiar de la época, en una sociedad eminentemente agraria por ocupación y rural por su hábitat (García Abad; Pareja; Zárraga, 2007). No obstante, la falta de información censal sobre las edades de los escolarizados, no permite aseverar las mismas tasas de infrafrecuentación escolar en la población 
infantil para las edades de escolarización obligatoria (6 a 9 años) que para las inmediatas superiores, en las que previsiblemente las tasas disminuirían mucho por abandono escolar -por motivos laborales en los niños, y motivos de sexo entre las niñas- y se agrandarían las diferencias de género (Julien, 2008).

Los mapas provinciales de frecuentación escolar, tanto de los niños como de las niñas (fig. 7A y 7B), dibujan con claridad dos grandes áreas con escolarización diferente: en la mayor parte de la mitad norte peninsular se alcanzan tasas más altas que las medias nacionales, mientras en la mitad sur y archipiélagos las tasas son inferiores a dichas medias. No obstante, parte de Cataluña y de la Comunidad Valenciana, y sobre todo Galicia, ofrecen excepciones notorias sobre el resto de la mitad norte peninsular, pues sus tasas de frecuentación escolar también son inferiores a las medias nacionales; en sentido negativo destacan las bajas tasas de escolarización de las niñas gallegas del interior regional, pues se sitúan a la cola de España (7,9\% en Lugo, 13,5\% en Orense), aunque es Canarias la región más abandonada en frecuentación escolar para ambos sexos, pues ésta sólo afecta al 17,2\% de los niños y al $10,4 \%$ de las niñas. Por su parte, entre las provincias del sur peninsular, Almería también bate records negativos, pues sólo frecuentan la escuela el 19\% de los niños entre los que tienen 6 y 15 años de edad, y el $12 \%$ de las niñas.

En cualquier caso, el mapa de frecuentación escolar masculino, con tasas mucho más altas que el de las niñas (fig. 7A y 7B), y tal vez por ello, dibuja contornos territoriales nítidos en sus distintas frecuencias: tanto las tasas máximas como las mínimas quedan bordeadas por la gradación de las tasas intermedias. En el mapa con las tasas femeninas, la distribución territorial de sus diversas frecuencias reproduce grosso modo el mapa masculino, aunque siempre con tasas mucho más bajas, mientras los contornos de sus diversas frecuencias ofrecen cierta irregularidad, en parte vinculada a las tasas más bajas de las niñas (fig. 7; cuadro 3). A nivel nacional, la tasa femenina de frecuentación escolar es un tercio menor que la de los niños $-27 \%$ y $41 \%$ respectivamente-, mientras esta diferencia relativa se mantiene grosso modo tanto en las provincias con tasas de escolarización más altas como en las que ésta es más baja; en los casos extremos se duplican los valores medios de infrafrecuentación femenina, como sucede, por una parte, en León (-61\% respecto a la tasa masculina) y, por otra en Lugo (-64\%) y en Orense (-65\%), provincias que se sitúan en los extremos positivo y negativo del ranking de frecuentación escolar (cuadro 3). Sólo en la Comunidad Valenciana se detecta una aparente situación de igualdad de género en la frecuentación escolar, con tasas incluso más favorables para las niñas en Castellón y en Valencia, aunque dicha paridad es resultado, sobre todo, de tasas bajas en los niños.

Entre los factores explicativos de las diferencias geográficas en las tasas de frecuentación escolar, hay que señalar que las tasas más altas nunca corresponden a las áreas más urbanas, como son Madrid, Barcelona, Sevilla o Valencia (fig. 12), sino al conjunto territorial formado por las provincias centrales de la mitad norte de la península, como son Álava, Burgos, Navarra, Segovia, Palencia, Soria, Santander y Logroño, casi todas ellas con tasas de población urbana en sus capitales inferiores a la media nacional -11,8\%-(fig. 7, 12 y cuadro 3). A continuación analizamos brevemente algunos de los factores aportados por el mismo censo de población de 1860, que, en parte, pueden explicar tanto las desiguales tasas de frecuentación escolar en género y territoriales, como las diferencias en los niveles de alfabetización, igualmente importantes entre hombres y mujeres. 


\section{III.1.1. La desigual dotación de maestros y maestras}

La dotación provincial de maestros y maestras de enseñanza primaria, medida con la ratio habitantes por maestro/a, se muestra como excelente indicador para valorar tanto la desigual distribución territorial de las tasas de frecuentación escolar como las de población alfabetizada, al mismo tiempo que pone de relieve la discriminación de niñas y maestras en los temas educativos. Esta discriminación femenina afecta a todos los territorios de España, pero, en contraposición a los varones, resulta más llamativa en las áreas más dependientes del empleo agrario, y menos en las provincias que en 1860 sobresalían en sus tasas de empleo en el sector secundario (fig. 8 A y B).

En efecto, los mapas con el número total de habitantes por cada maestro/a (fig. 9 A y B), así como sus cifras especificadas en el cuadro 3, nos muestran que las provincias con mejores dotaciones de maestros varones, se superponen con las provincias que alcanzan tasas más altas tanto en frecuentación escolar masculina (fig. 7A y fig. 9A) como en varones alfabetizados (fig. 13A y 14A); es una lógica correspondencia entre causa y efecto, o entre oferta y demanda educativas. Por el contrario, las provincias con tasas más bajas de escolarización y de alfabetización masculinas, también son las peor dotadas de maestros varones; en este caso el número de habitantes por maestro duplica, o incluso triplica, la dotación media nacional -1.008 habitantes por maestro-. En su conjunto, pues, muestran clara interdependencia los mapas provinciales que informan sobre los indicadores educativos masculinos aportados por el censo de población de 1860, es decir maestros censados por número de habitantes (fig. 9A), tasas masculinas de frecuentación escolar sobre niños de 6 a 15 años de edad (fig. 7A) y tasas de varones alfabetizados sobre población de 11 y más años de edad (fig. 13A y 14A).

Además, como se analizará después, la interdependencia entre los tres mapas indicados se refuerza con otros indicadores que también parecen influir en la educación primaria, como son la dotación de clérigos seculares en tanto que apoyo en la enseñanza primaria, y la importancia relativa de los jornaleros del campo -y por defecto de los propietarios y arrendatarios agrícolas- en tanto que clase social con repercusión en la valoración y en las posibilidades de inversión educativa. En todos los mapas masculinos indicados, cada uno de los cuatro intervalos de intensidad establecidos - dos con cifras superiores a la media nacional, y dos con cifras inferiores-, tienen distribución espacial de provincias en manchas compactas, que a su vez dibujan gradaciones desde las intensidades mayores en la región central de la mitad norte peninsular, para terminar con las menores -o deficientes- intensidades en el sur y en Canarias.

El mapa que muestra el censo de maestras por provincias (fig. 9B) ofrece dotaciones de docentes mucho menores que en los varones, y una distribución territorial de sus intensidades bien diferente. Así, las provincias del centro de la mitad norte peninsular, que son las que acumulan la mejor dotación de maestros varones, tienen, en cambio, una dotación de maestras muy deficiente: así, Álava que tiene 1 maestro por 350 habitantes, sube a 1.959 habitantes por cada maestra, mientras en Burgos las ratios son 426 habitantes por maestro y 4.378 por maestra, en León 399 y 4.003, respectivamente, y con diferencias algo atenuadas pero también muy altas se encuentran Oviedo, Santander o Soria. Sin embargo, estas bajas dotaciones de maestras en las provincias centrales de la mitad norte peninsular, se reflejan sólo relativamente en la contracción de las tasas de frecuentación escolar femenina, pues éstas son relativamente altas dentro de las de su género (fig. 7B), aunque las diferencias con las tasas 


\section{Figura $8 \mathrm{~A}$}

ESPAÑA, 1860. DISTRIBUCIÓN PROVINCIAL DE LA POBLACIÓN ACTIVA, SEGÚN SECTOR ECONÓMICO, $\%$ SOBRE TOTAL ACTIVOS DE CADA PROVINCIA. SECTORI

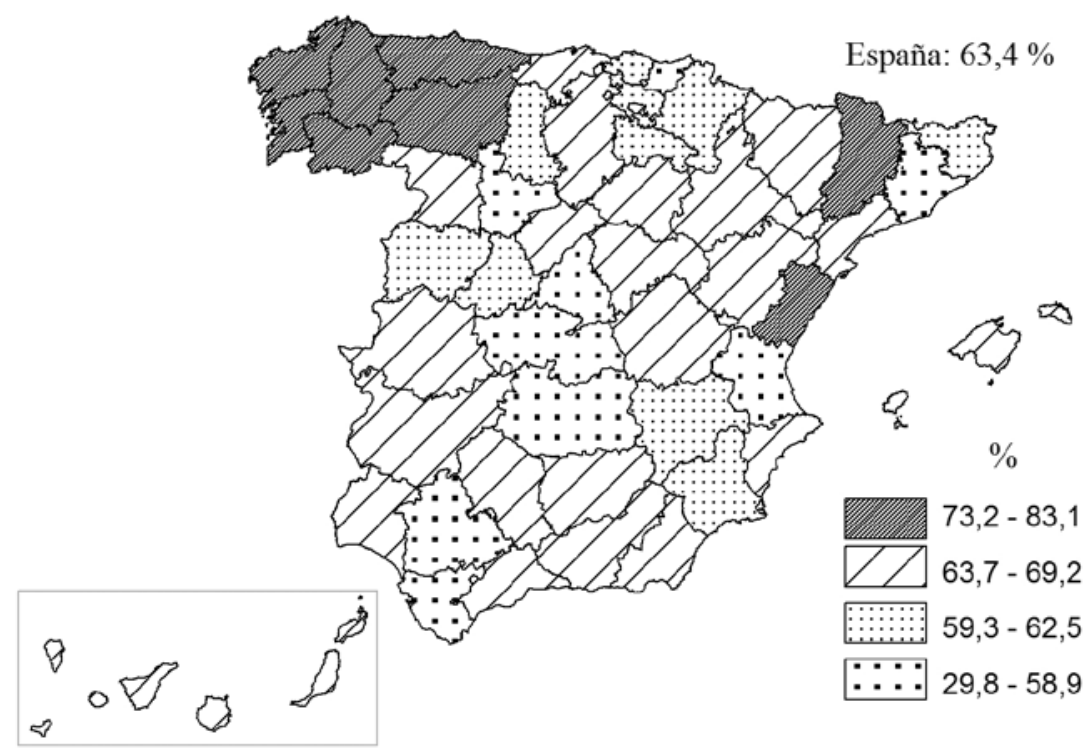

Figura 8B

ESPAÑA, 1860. DISTRIBUCIÓN PROVINCIAL DE LA POBLACIÓN ACTIVA, SEGÚN SECTOR ECONÓMICO, \% SOBRE TOTAL ACTIVOS DE CADA PROVINCIA. SECTOR II

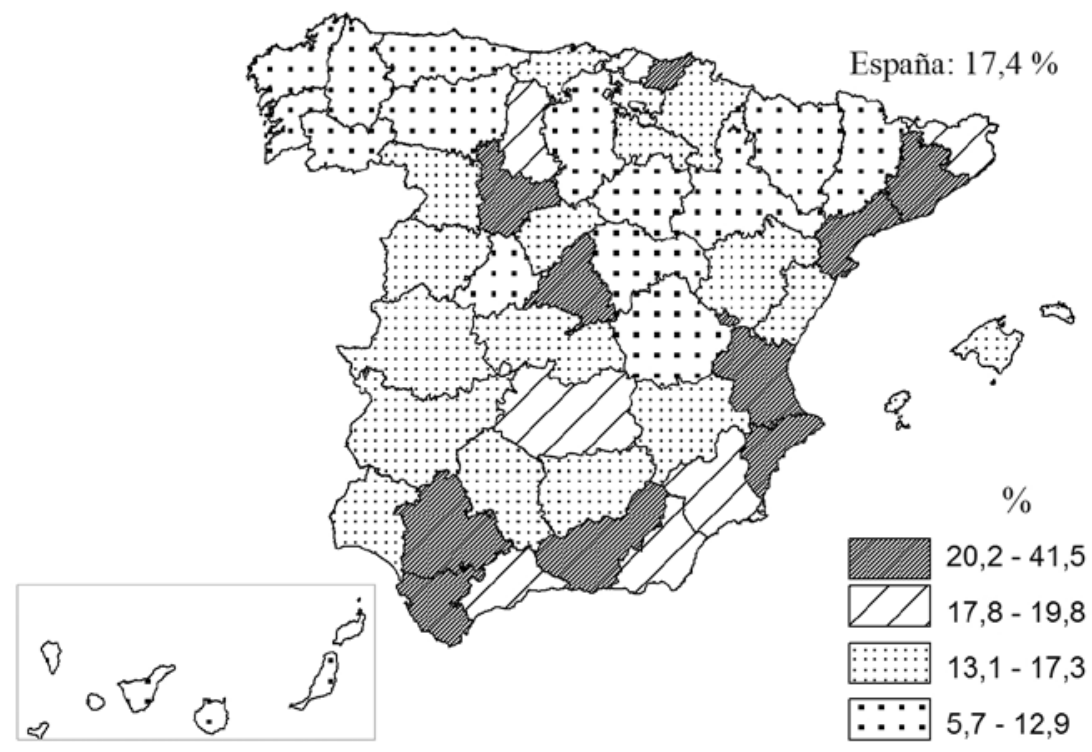

Fuente: Junta General de Estadística: Censo de la población de España de 1860. 
masculinas sí son importantes: en León la escolarización de las niñas es un 61\% inferior a la de los niños, un $40 \%$ en Burgos, $49 \%$ en Santander ó 47\% en Soria (cuadro 3). Por todo ello, el déficit de maestras estaría compensado con aulas de niñas mucho más pobladas que las de niños y, en parte, con escuelas mixtas - de niños y niñas- previstas por la Ley de Instrucción Pública de 1857 para las escuelas incompletas (art. 103), muy frecuentes pues la mayoría de los municipios censan menos de 500 habitantes.

El mayor déficit de dotación de maestras -entre 2.800 y 12.357 habitantes por maestra-, que se localiza en las provincias de la mitad norte peninsular y en Canarias (fig. 9B), en parte parece relacionado con las provincias donde es mayor la dependencia del empleo agrario y menor la dependencia del empleo en el sector secundario (fig. 8). Por el contrario, las provincias de la costa mediterránea, todas con tasas de activos en el sector secundario superiores a la tasa media nacional $-17,4 \%$-, suelen ofrecer ratios de habitantes por maestra más bajas, o más favorables, que la media nacional -2.010 habitantes por cada maestra-. En conclusión, la dotación de maestras en relación al número de habitantes, con frecuencia muestra menores dotaciones de maestras donde el empleo es más agrario y menos industrial. En cualquier caso, Galicia es la región que concentra las menores dotaciones de maestras: en Pontevedra hay 4.000 habitantes por maestra, en Coruña 6.000, en Orense 10.500 y en Lugo 12.300; asimismo esta región es la que padece las tasas más bajas de escolarización femenina (fig. 7B) y de mujeres alfabetizadas (fig. 13B y 14B). Por el contrario, las mejores dotaciones de maestros varones en parte se corresponden con la mayor importancia del empleo agrario con propietarios y arrendatarios.

\section{III.1.2. El clero secular como apoyo en la docencia impartida en las escuelas primarias}

La implicación del clero secular en la docencia impartida en las escuelas primarias (Rodríguez de Gracia, 2007), la deducimos tanto del texto de la Ley de Instrucción Pública de 1857 como de la información estadística del Censo de población de 1860; con la fuente censal se ha cartografiado la presencia relativa del clero secular (fig. 10), que parece se relaciona con la frecuentación escolar (fig. 7) y con las tasas de población rural alfabetizada (fig. 13). El articulado específico de la Ley y los resultados de estos tres mapas parecen interdependientes, sobre todo en el caso de la frecuentación escolar masculina, los varones rurales alfabetizados y la dotación de clero secular, en este caso medido con tasas por 1.000 habitantes.

En efecto, conviene tener presente el protagonismo que la Ley de Instrucción Pública de 1857 otorga al clero secular de las parroquias en la instrucción primaria. La Ley habilita a los párrocos (junto a los secretarios de los ayuntamientos) para que ejerzan como maestros en las escuelas «incompletas» de los municipios con menos de 500 habitantes (art. 189) ${ }^{10}$. En este sentido hay que subrayar que en las provincias con mayores tasas de escolarización, los municipios con menos de 500 habitantes suelen sumar la mitad o más del total (así, en Segovia estos municipios son el $68 \%$ del total, en Soria el $76 \%$ o en Burgos el 64\%), mientras el censo medio de estos municipios se sitúa entre los 200 y 300 habitantes.

10 De hecho, la Ley Moyano no incluye sueldo fijo para los maestros que pudieran ejercer en municipios con menos de 500 habitantes, es decir que en la práctica parece que en estos pueblos rurales no se contemplan escuelas de enseñanza pública elemental completa (art. 191), ni el ejercicio de maestros con título oficial. 
ESPAÑA, 1860. NÚMERO DE HABITANTES POR CADA MAESTRO, SEGÚN PROVINCIAS

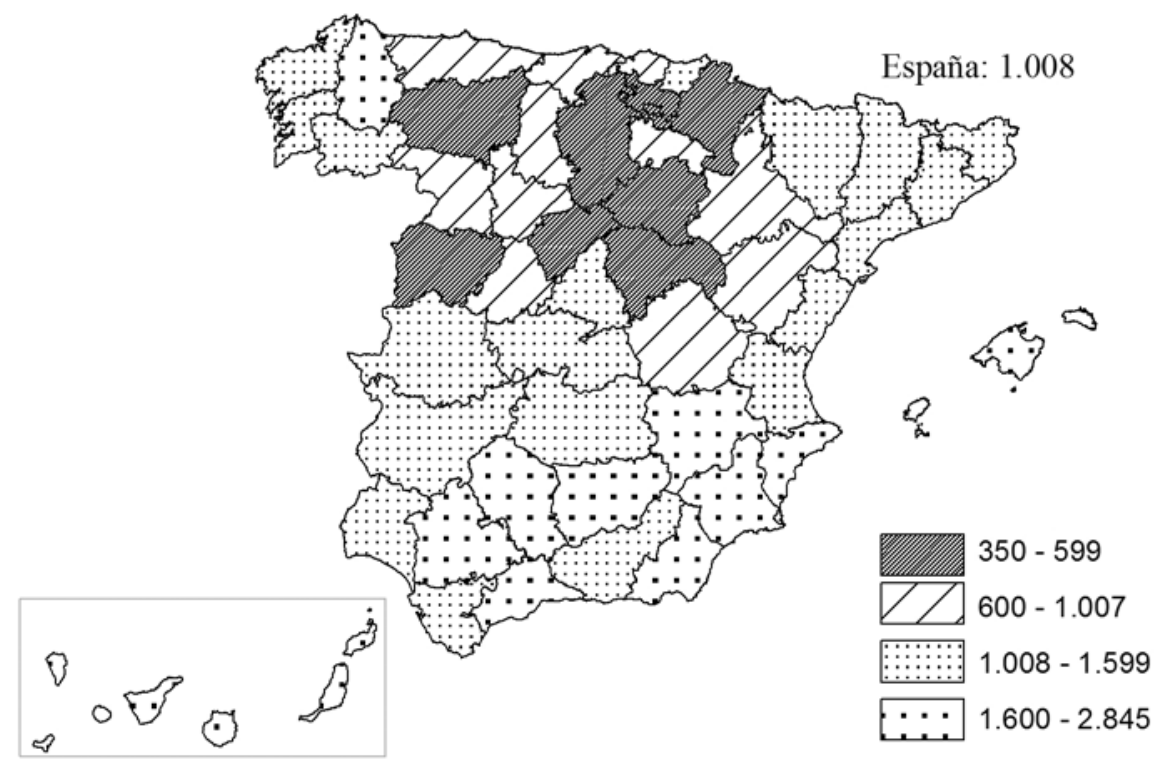

Figura 9B

ESPAÑA, 1860. NÚMERO DE HABITANTES POR CADA MAESTRA, SEGÚN PROVINCIA

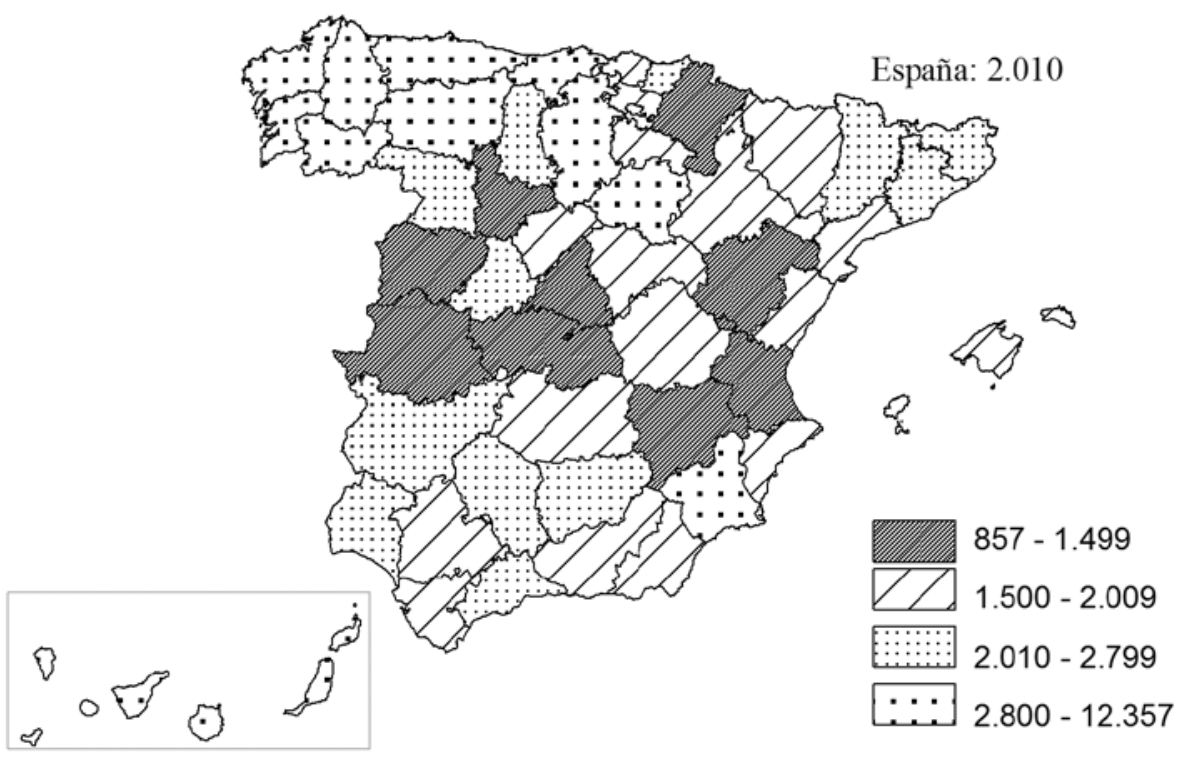

Fuente: Junta General de Estadística: Censo de la población de España de 1860. 
En general, las provincias con tasas más altas de frecuentación escolar (fig. 7), coinciden con la mayor presencia de clero secular censado, frecuentemente con tasas superiores a 4 sacerdotes por 1.000 habitantes -España, 2,7- (fig. 10). Por el contrario, las provincias con las menores tasas de clero secular, entre 1,1 y 1,9 sacerdotes por 1.000 habitantes, todas en la mitad sur de la península, incluido el archipiélago canario, se superponen con nitidez a las provincias con menor escolarización, sobre todo de niños (fig. 7A y fig. 10). Este previsible magisterio del clero secular, contaba con ventajas económicas reconocidas en la Ley de Instrucción Pública, tanto para la Administración como para los sacerdotes, pues «Los que disfruten de prebenda eclesiástica percibirán sólo la mitad del sueldo que les corresponda como Profesores» (art. 176).

Por otra parte, el magisterio del clero en las escuelas primarias, no sólo se podía ejercer legalmente en las escuelas «incompletas» (Art. 189), sino que a las autoridades de la Iglesia Católica la Ley Moyano les permitía inspeccionar los contenidos de la enseñanza para que fuesen acordes a la doctrina de la Iglesia, así como velar por la educación religiosa de la juventud (art. 295, 296); para conseguir estos fines «El Gobierno procurará que los respectivos curas párrocos tengan repasos de Doctrina y Moral cristiana para los niños de las escuelas elementales, lo ménos una vez cada semana» (art. 10).

\section{III.1.3. La clase social como determinante de la frecuentación escolar}

La clase social del cabeza de familia y la reproducción social es un reconocido indicador explicativo de las diferencias territoriales en la frecuentación escolar (Julien, 2008. García Abad; Pareja; Zárraga, 2007). A falta de informaciones socioeconómicas más específicas sobre el cabeza de familia, tal como aportan los autores indicados, utilizamos dos de los datos publicados en el censo de 1860: a) Proporción de los jornaleros del campo. Éstos, según el recuento censal, suman para España 2.354.068, es decir más de la mitad de los que trabajan en el sector primario, que, a su vez, reúne al $63 \%$ de todos los activos del país; el anverso de los jornaleros como clase social serían los propietarios y arrendatarios agrícolas. b) Proporción de varones alfabetizados. Éstos también son indicador que induce a su reproducción social mediante la escolarización de sus hijos.

En efecto, los jornaleros del campo (fig. 11) son sin duda un indicador adecuado de clase social desfavorecida y muy representativa en la España de 1860. La clase social de los jornaleros del campo tendría escasas posibilidades económico-culturales y baja valoración acerca de los beneficios de una inversión escolar para los hijos de estos hogares, sobre todo en el caso de las niñas. Tal como muestran las cifras del cuadro 3 y fig. 11, las provincias con menor representación relativa de estos jornaleros $-\mathrm{y}$, por tanto, mayor presencia de propietarios agrícolas-, se corresponden con las proporciones más altas de frecuentación escolar y de alfabetización rural (fig. 7, fig. 13 y cuadro 3 ). Por el contrario, cuando las tasas cambian de signo, las mayores tasas de jornaleros del campo se superponen a las tasas más bajas de frecuentación escolar, y también a las menores tasas de varones alfabetizados.

En cualquier caso, las influencias de la clase social y de su reproducción social en la frecuentación escolar, también están sometidas a la generalizada discriminación educativa femenina, que arranca en la niñez escolar y se prolonga durante la vida adulta, tal como ha sido analizada. La clase social del cabeza de familia, manifestada sobre todo en su ocupación 
Figura 10

ESPAÑA, 1860. PRESENCIA DE «ECLESIÁSTICOS》 (CLERO SECULAR)

EN LAS PROVINCIAS POR 1.000 HABITANTES

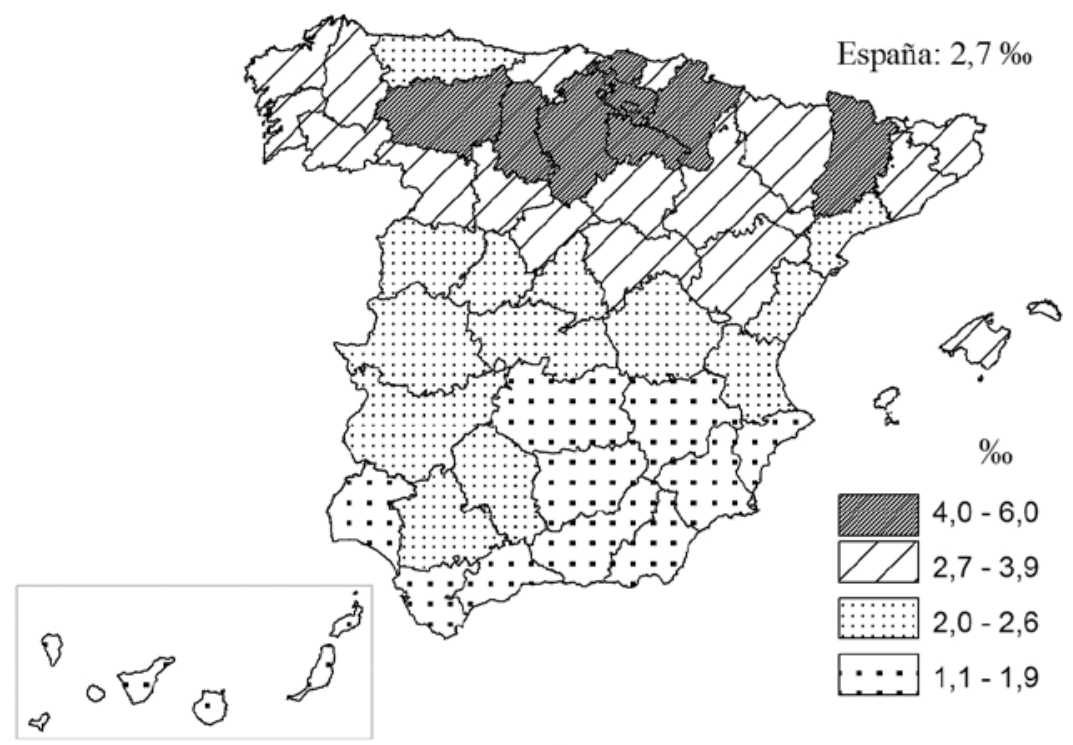

Fuente: Junta General de Estadística: Censo de la población de España de 1860.

Figura 11

ESPAÑA, 1860. PROPORCIÓN (\%) DE JORNALEROS DEL CAMPO, SOBRE EL TOTAL DE EMPLEO EN EL SECTOR PRIMARIO (PROPIETARIOS, ARRENDATARIOS, JORNALEROS DEL CAMPO)

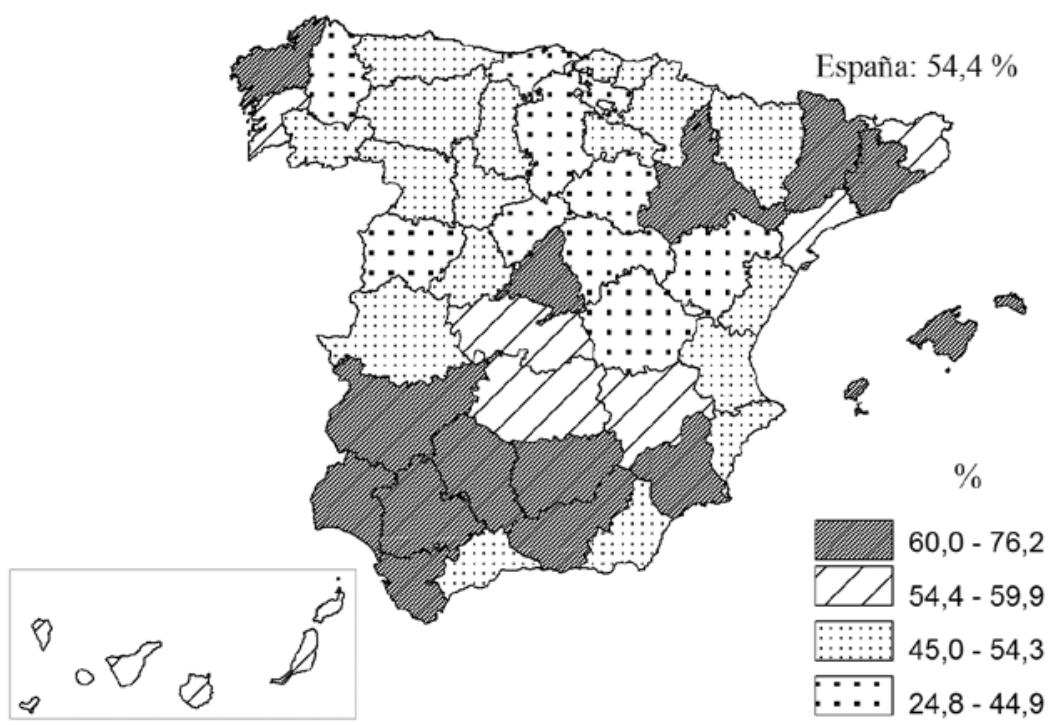

Fuente: Junta General de Estadística: Censo de la población de España de 1860. 


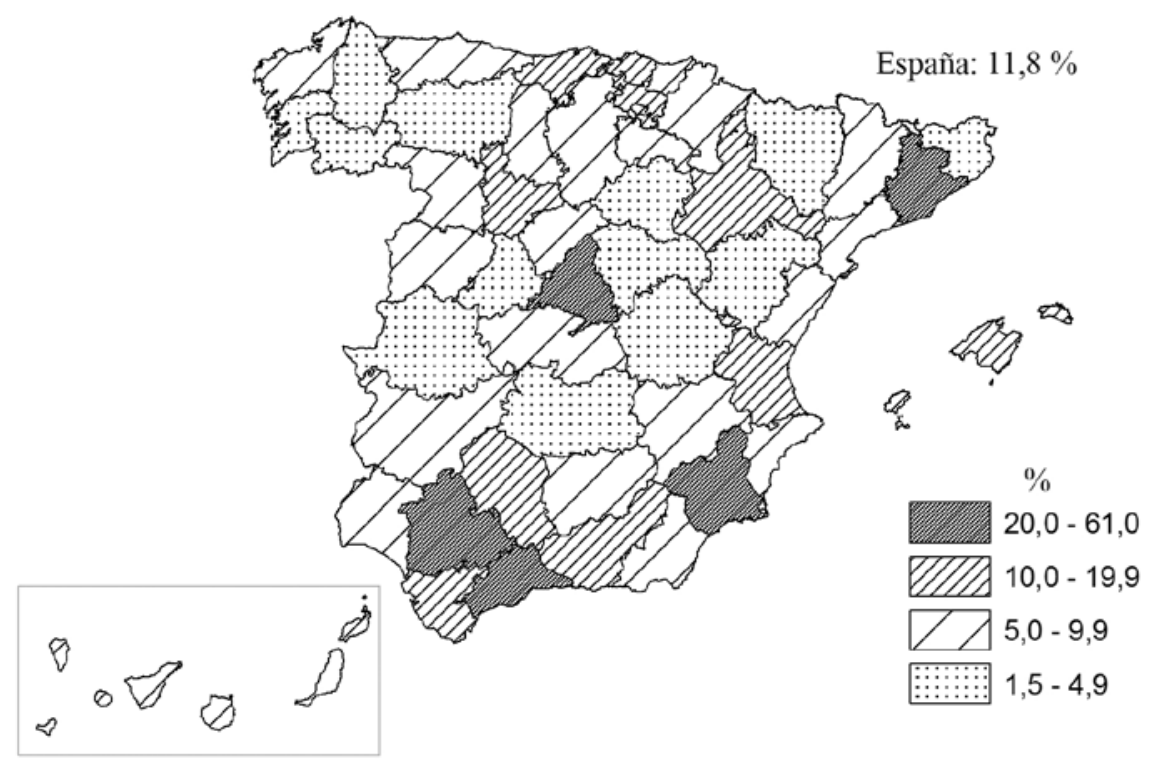

Fuente: Junta General de Estadística: Censo de la población de España de 1860.

laboral, es, según los autores que han estudiado este tema con información censal detallada, el factor más influyente en la frecuentación escolar.

\section{III.2. Población alfabetizada según género, hábitat y territorios}

La información censal de 1860 permite elaborar mapas con tasas de alfabetizados, es decir población que sabe leer y escribir en relación a la que tiene 11 y más años de edad. Los criterios diferenciadores utilizados en los mapas son el género -hombres y mujeres- tanto para los que residen en hábitat urbano - población que reside en las capitales de provinciacomo en hábitat rural -resto de la población provincial-. Las diferencias territoriales son muy acusadas entre las provincias centrales de la mitad norte de la península, mucho más alfabetizadas, y las del sur, con tasas más bajas; a su vez, la menor alfabetización de los territorios meridionales también se extiende a Galicia, a una amplísima franja que bordea todo el litoral mediterráneo y a los archipiélagos. En consecuencia, la distribución territorial de las tasas de alfabetizados según intensidad, se superpone, en buena lógica, con los mapas de frecuentación escolar, ya analizados. Las diferencias territoriales de los niveles de alfabetización dibujan espacios más compactos para los varones - por sus tasas más altas- que para las mujeres, con tasas más bajas, tan vinculadas a su conocida discriminación educativa.

La población urbana residente en las capitales de provincia sólo representa el 11,8\% del total de España (fig. 12), es decir en 1860 el conjunto del país era eminentemente 
rural por su hábitat. Tasas de población urbana más altas que la media de España sólo se contabilizan en 15 de las 49 provincias; en general la mayor urbanización corresponde a las provincias donde se ubican las ciudades mayores, entre las que destaca en solitario Madrid cuya población urbana representa el $61 \%$ de su provincia, seguida a mucha distancia por Barcelona (26\%), Sevilla (25\%) y Málaga $(21,2 \%)$; la tasa de población capitalina de Murcia -22,9\% - es efecto, igual que ocurre en la actualidad, de las características de su término municipal, muy extenso y con mucha población distribuida en disperso y en pequeños núcleos, vinculados a su agricultura muy intensa en la huerta del río Segura. Por el contrario, tienen tasas de urbanización -referida sólo a la población residente en el municipio de la capital provincia- inferiores al 10\% de la población provincial, 34 de las 49 provincias, y de ellas 13 no alcanzan el 5\% de población urbana; Galicia es la región más poblada de España (1.799.244 habitantes ó el 11,5\% del total), la más densa, con media de $61 \%$ habit. $/ \mathrm{km}^{2}$, que supone el doble que la densidad nacional, y también la más rural, pues su tasa de población urbana cae al 1,5\% en Pontevedra, al 2,9\% en Orense, al $4,9 \%$ en Lugo y al 5,4\% en Coruña.

a) En habitat rural los varones alfabetizados (fig. 13A) son el 39,2\% de los que tienen 11 y más años de edad. Las tasas más altas de alfabetizados se concentran en la parte central de la mitad norte peninsular. El área con mayor alfabetización -tasas entre 74\% y 81\%corresponde a las provincias contiguas de Álava, Burgos, Palencia, Santander y Soria, cuya periferia queda envuelta por el resto de provincias con tasas superiores a la media nacional (39,3\%); las provincias indicadas con las mayores tasas de alfabetización también son las que alcanzan la mayor frecuentación escolar (entre 67\% y 75\% de los varones entre 6 y 15 años de edad). Como causa común de estos niveles más altos de escolarización y alfabetización de los varones, seguramente hay que citar, por una parte, mayor dotación aquí de maestros y mayor presencia de clero secular (entre 4 y 6,7 clérigos censados por 1.000 habitantes, fig. 10), pues, como se ha indicado, la Ley Moyano de 1857 les permitía el magisterio en las escuelas primarias, especialmente en los municipios con menos de 500 habitantes, según se estudió en epígrafe anterior; y por otra parte, estos mayores niveles de escolarización y alfabetización también se corresponden con las tasas más bajas de jornaleros del campo (fig. 11) (entre $25 \%$ y $47 \%$ de jornaleros sobre el total de activos en el sector primario), como clase social representativa y determinante en la baja valoración de la inversión escolar para los hijos (Julien, 2008; García Abad et al., 2007).

No obstante, la mayor parte de las provincias (27 de 49) tienen tasas de varones rurales alfabetizados inferiores a la media de España -39,3\%-; estos también distribuyen sus niveles de alfabetización con gran regularidad territorial, es decir en círculos contiguos y decrecientes respecto al área más alfabetizada de España (fig. 13A). En cualquier caso, las provincias con los varones rurales menos alfabetizados -tasas entre $18 \%$ y $30 \%$, en 14 provinciasalcanzan niveles más favorables que el grupo de mujeres rurales más alfabetizadas, pues éstas sólo alcanzan tasas entre $15 \%$ y $23 \%$, en 10 provincias (fig. 13B), lo cual resalta de modo extraordinario la discriminación femenina en la instrucción más elemental, a resultas de la prioridad para los varones en la inversión familiar educativa.

b) Las mujeres con residencia rural en 1860 tienen tasas de alfabetización muy bajas (fig. 13B), entre 2,6\% en Orense y 23,3\% en Logroño, con media nacional de sólo 9,3\%. Estas tasas tan reducidas sin duda fuerzan a una notable dispersión de sus valores numé- 


\section{Figura 13A}

ESPAÑA, 1860. HÁBITAT RURAL (RESIDENTES DE LA PROVINCIA, MENOS LA CAPITAL). VARONES QUE SABEN LEER Y ESCRIBIR: PROPORCIÓN (\%) SOBRE LA POBLACIÓN RURAL MASCULINA DE 11 Y MÁS AÑOS DE EDAD

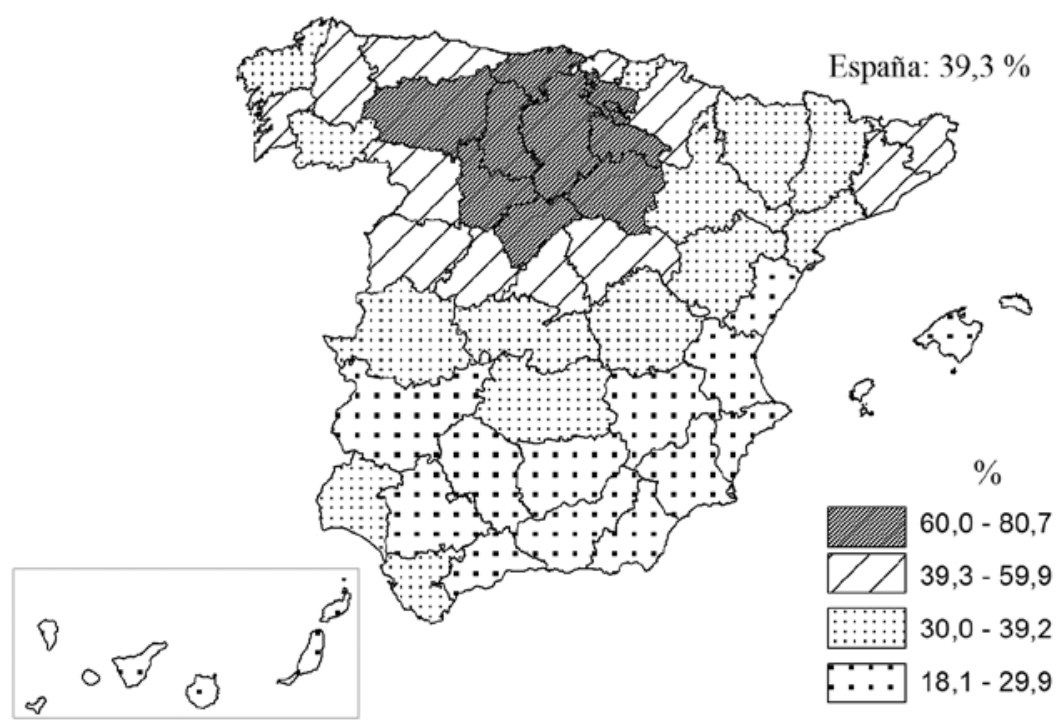

Figura 13B

ESPAÑA, 1860. HÁBITAT RURAL (RESIDENTES EN LA PROVINCIA MENOS LA CAPITAL). MUJERES QUE SABEN LEER Y ESCRIBIR: PROPORCIÓN (\%) SOBRE LA POBLACIÓN RURAL FEMENINA DE 11 Y MÁS AÑOS DE EDAD

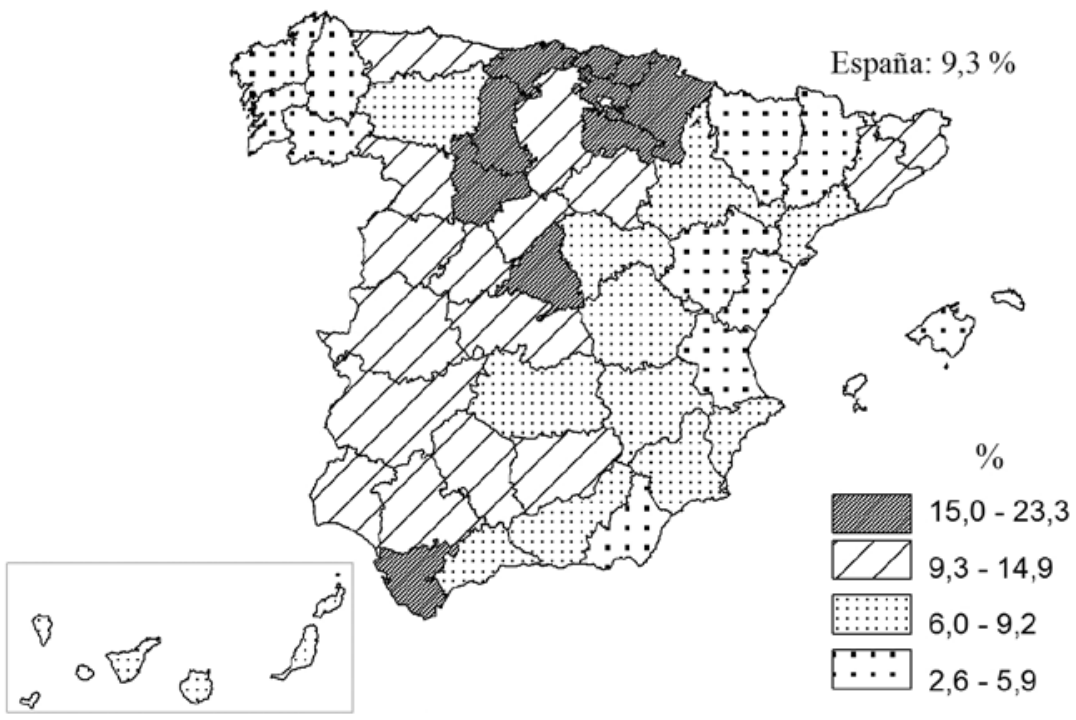

Fuente: Junta General de Estadística: Censo de la población de España de 1860. 
ricos en la distribución territorial; así, la tasa menor femenina -2,6\%- se multiplica por nueve para alcanzar la tasa más alta $-23,3 \%$-, frente al 4,5 que necesitan los varones -desde el 18,1\% en Canarias, hasta 80,7\% en Santander-. En cualquier caso, Galicia es la región más uniforme en la discriminación educativa femenina, pues su tasa de alfabetización -sobre población con 11 y más años de edad- más favorable sólo alcanza al 5,5\% en Coruña.

c) En las capitales de provincia las tasas de alfabetización aumentan mucho (fig. $14 \mathrm{~A}$ y B), sobre todo entre las mujeres: los varones alcanzan una tasa media de alfabetizados del $58,5 \%$, y las mujeres el 30,2\%; es decir los aumentos relativos en hábitat urbano respecto a las tasas en hábitat rural son del $49 \%$ entre los varones y del $225 \%$ entre las mujeres. $\mathrm{Al}$ aumentar mucho las tasas de alfabetizados en las capitales, su reparto territorial es menos disperso, sobre todo entre las mujeres.

La mejora de las tasas de alfabetizados urbanos respecto a las de la población rural, supone que en las capitales no existe el equivalente a las tasas rurales más bajas, sobre todo entre las mujeres (fig. 13, A y B y fig. 14, A y B). En efecto, entre las mujeres rurales había 21 provincias con tasas de alfabetizadas entre 2,6\% y 9,2\%, mientras en Murcia, la capital con menor tasa de alfabetizadas, ésta es de 9,9\%; en este último caso se trata, como se indicó, de una población que en su mayor parte no vive en la ciudad capital, sino en hábitat rural dentro de un término municipal muy extenso y con población dedicada a la agricultura de huerta.

Como ocurre con la población rural, las capitales también alcanzan sus mayores tasas de alfabetización en la parte central de la mitad norte de la península, aunque en ambos tipos de hábitat destacan las «islas» positivas de mujeres alfabetizadas de Cádiz y Madrid, sin duda vinculadas a las funciones portuarias y de capital del Estado, respectivamente, de estas dos ciudades. El resto de las provincias con grandes ciudades (Barcelona, Valencia, Sevilla, las tres con más de 100.000 habitantes, así como Málaga, Zaragoza o Granada, con más de 67.000) no repercuten directamente en una mayor alfabetización de su población femenina, pues mantienen tasas inferiores a la media nacional (fig. 14B). Por el contrario, las tasas de alfabetización más altas se concentran en las provincias centrales de la mitad norte peninsular, donde el peso demográfico de sus capitales, en su gran mayoría, se mantiene por debajo del $10 \%$ de la población provincial.

El mayor grado de alfabetización de la población que reside en las capitales, está vinculado a la concentración en ellas de los activos necesariamente alfabetizados y/o con estudios medios y superiores, por requerirlo el ejercicio de sus profesiones: entre ellos se encontrarían los activos del sector terciario, excluidos los masivos sirvientes; los fabricantes, industriales y artesanos, así como los propietarios agrícolas más destacados. Todas estas profesiones, altamente concentradas en las capitales de provincia, forman una clase social cuya reproducción induce a una mayor instrucción en ambos sexos, aunque la discriminación femenina se mantenga muy patente; el mayor incremento relativo en las tasas de alfabetización de las mujeres urbanas respecto a las rurales, se explicaría por sus bajísimas tasas en medio rural, donde las labores del hogar, el servicio doméstico y, previsiblemente, el jornalerismo agrario, sumarían casi la totalidad de las actividades femeninas, y que en ningún caso requieren, necesariamente, la alfabetización. 


\section{Figura 14A}

ESPAÑA, 1860. HABITAT URBANO (RESIDENTES EN EL MUNICIPIO DE LA CAPITAL DE LA PROVINCIA). VARONES QUE SABEN LEER Y ESCRIBIR: PROPORCIÓN (\%) SOBRE POBLACIÓN URBANA MASCULINA DE 11 Y MÁS AÑOS DE EDAD

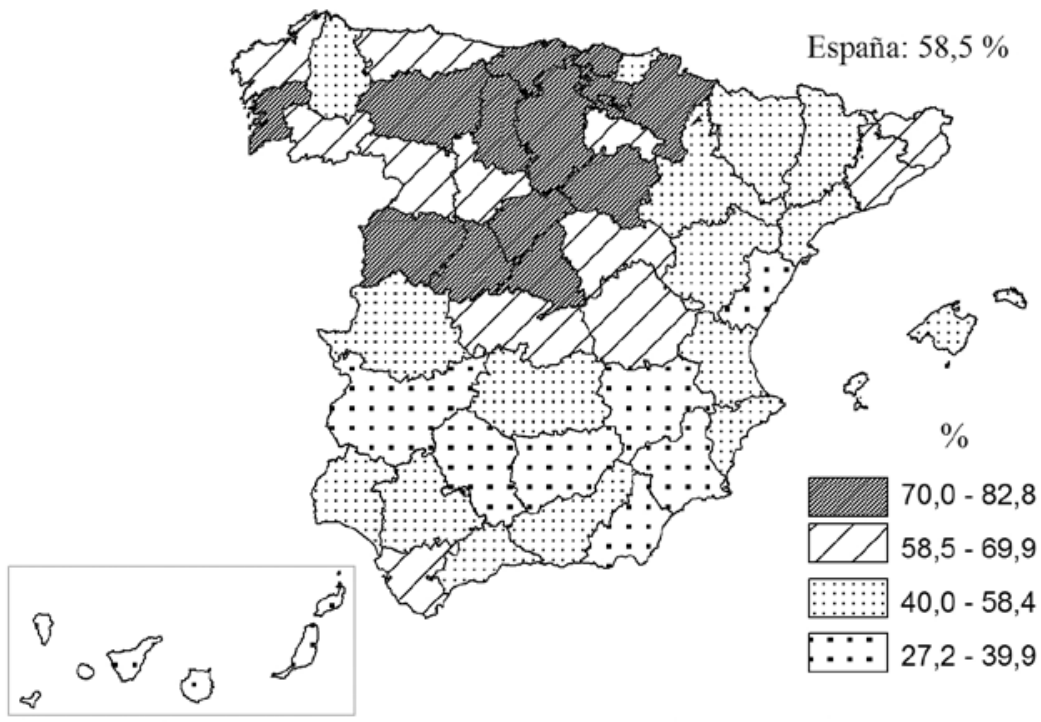

Figura 14B

ESPAÑA, 1860. HABITAT URBANO (RESIDENTES EN EL MUNICIPIO DE LA CAPITAL DE LA PROVINCIA). MUJERES QUE SABEN LEER Y ESCRIBIR: PROPORCIÓN (\%) SOBRE POBLACIÓN URBANA FEMENINA DE 11 Y MÁS AÑOS DE EDAD

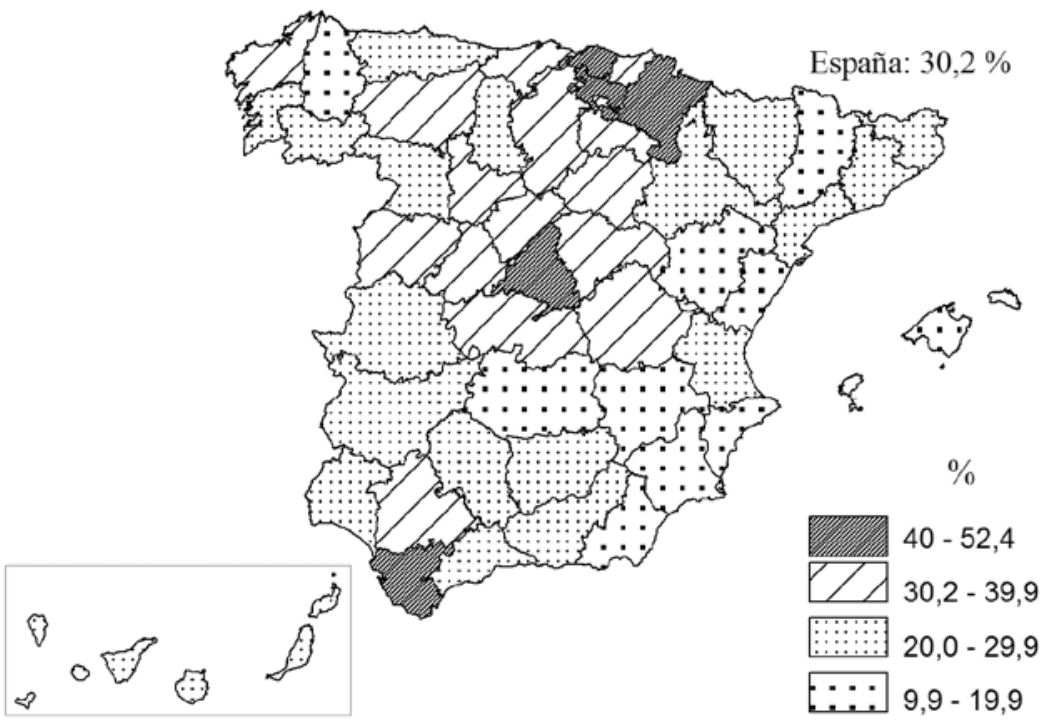

Fuente: Junta General de Estadística: Censo de la población de España de 1860. 


\section{CONCLUSIONES}

El Censo de la población de España de 1860 es un valioso documento para la Geografía histórica y para los historiadores, elaborado hace 154 años mediante datos personales y familiares de los 15.658.586 de habitantes que en la fecha censal residían de hecho en España. Las finalidades aplicadas (fiscales, militares, políticas, ...) que desde siempre habían tenido los censos de población, se potencian de modo extraordinario en los censos modernos impulsados por los gobiernos durante el siglo XIX; éstos explicitan, como es el caso de España, los variados beneficios sociales, económicos, o para la mejora de la gobernabilidad del país, que esperan obtener de los censos. Así, de acuerdo con estos potenciales beneficios de los censos, se justifican las profundas y costosas incursiones decenales de los censos para conocer, de forma creciente, la vida individual y de las familias, y así formar un cuerpo de conocimientos estadísticos objetivos con los que poder guiar el país hacia crecientes cotas de progreso en el conjunto del territorio y en sus regiones.

En este sentido, la España de 1860 se encuentra en un momento de imperiosa necesidad de elaborar un censo de la población que cumpla los dos objetivos básicos que se asignaban a los censos: la exhaustividad del recuento numérico de la población y unas estadísticas sociales útiles para planificar programas de desarrollo. En efecto, España tenía una base sociodemográfica y económica deficitaria, pero a corto plazo se creía vislumbrar cambios importantes positivos en su progreso. Así, España era un país de economía fundamentalmente agraria, pero en transformación, con hábitat rural muy predominante, y con nivel de instrucción básica muy deficitario, singularmente entre las mujeres. Los inminentes progresos económicos del país, que iban a contar con la expansión de los ferrocarriles y carreteras, o con nuevos focos industriales en el norte de la península, entre otros, quedan bien reflejados en los manuales de historia que califican la década 1856-1866 con significativos títulos, como «La expansión económica, 1856-1866» ó «La Sociedad Satisfecha, 1856-1866» (R. Carr, 1969).

Con estas premisas, para este primer trabajo sobre el censo de población de 1860 se ha elegido el estudio de las dos variables tal vez más significativas y útiles a los intereses del país, evaluadas con la óptica del momento: comprobar la exhaustividad del empadronamiento de la población realizado sólo tres años antes, en el censo de 1857, y estudiar a escala de provincia -según género y hábitat rural y urbano- la primera variable social que introduce con detalle municipal un censo de España: el nivel de frecuentación escolar básica y el nivel de alfabetización alcanzado.

Las dudas de la Comisión de Estadística sobre la exhaustividad del empadronamiento de 1857 es la razón básica que llevó a «repetir» el censo de población en 1860. Las autoridades estadísticas españolas publican sendas introducciones en los dos primeros censos que les honran como profesionales, al eliminar toda sombra de autocomplacencia en los resultados numéricos de ambos censos. La falta de tradición en infraestructuras para confeccionar estadísticas demográficas, por una parte, y la importancia de eliminar omisiones censales, juzgadas decisivas para tomar decisiones importantes en las planificaciones del Estado, por otra, explican comportamientos tan extremos como publicar en el mismo censo de 1860 los resultados sintéticos de un cuestionario pedido a los ayuntamientos, para que éstos valoraran las causas de las disminuciones censales -si las hubiera- en el segundo censo. 
La escasa alfabetización de España era un problema crucial en 1860, sobre todo si se tiene en cuenta el desarrollo económico que se produce a partir de 1856. Para la variable educación primaria las estadísticas que aporta el censo permiten analizar las tasas de frecuentación escolar y las de alfabetizados, unas y otras dominadas por las desigualdades de género, con discriminaciones extremas para la mujer, tanto a escala regional como de hábitat, especialmente para el rural. La concentración del sector terciario «alfabetizado» en las capitales de provincia, la desigual distribución regional de las clases sociales que se originan en el sector primario, sobre todo entre jornaleros del campo, de una parte, y propietarios agrícolas, de otra, así como la omnipresente discriminación femenina en lo que concierne a la educación, explican a grandes rasgos la necesidad del estudio geográfico de la variable educativa, crucial para progresar en el desarrollo económico, social y político de España, que se encontraba, precisamente, en situación de cambio positivo en la educación a raíz de la recién promulgada Ley de Instrucción Pública de 1857.

\section{FUENTES}

Censo Español executado de Órden del Rey comunicada por el Excelentísimo Señor Conde de Floridablanca, Primer Secretario de Estado y del Despacho, en el año de 1787, En la Imprenta Real. Edición facsímil realizada por el Instituto Nacional de Estadística en 1981, con motivo de «1856-1981, CXXV Aniversario de la Estadística Oficial Española».

Comisión de Estadística General del Reino (1858): Censo de la población de España, según el recuento verificado en 21 de mayo de 1857, Madrid, Imprenta Nacional, XXIII +865 pp.

Comisión de Estadística General del Reino (1859): Anuario Estadístico de España, 1858, Madrid, Imprenta Nacional, VII +711 pp.

Comisión de Estadística General del Reino (1860): Anuario Estadístico de España correspondiente a 1859 y 1860, Madrid, Imprenta Nacional, XXV+599 pp.

Dirección General del Instituto Geográfico y Estadístico (1888): Reseña Geográfica y Estadística de España, 1888. En el «Prólogo», el General Carlos Ibáñez, Director General de la Dirección General del Instituto Geográfico y Estadístico, enumera los autores de los 23 artículos de que consta la Reseña; entre éstos, Federico de Olive, del Cuerpo de Estadística, redactó el subcapítulo «Censos» dentro del capítulo «Población».

Instituto Nacional de Estadística (INE)(1981): 1856-1981, CXXV aniversario de la Estadística Oficial. Documentos. Primeras disposiciones, Marid, 26 pp. (sn).

Junta General de Estadística (1862:1863): Anuario Estadístico de España, 1860: 1861, Madrid, Imprenta Nacional, XLI+880 pp.

Junta General de Estadística del Reino (1863): Memoria sobre el movimiento de la población de España en los años 1858, 1859, 1860 y 1861, Madrid, Imprenta de Luís Beltrán, calle del Sacramento, núm. 10. La Memoria incluye: «Exposición», XI páginas; «Recopilación de las leyes, decretos, reales órdenes y circulares de la Junta General de Estadística, que se refieren al movimiento de la población», XXXVIII páginas; «Memoria», 79 páginas.

Junta General de Estadística (1863): Censo de la población de España, según el recuento verificado en 25 de diciembre de 1860, Madrid, Imprenta Nacional, LXXXVIII+819 pp.

Junta General de Estadística (1866:1867): Anuario Estadístico de España, 1862:1865, Madrid, Imprenta Nacional, VII +920. 


\section{BIBLIOGRAFÍA}

ARDIT, M.; BADENES, M.À.; BERNAT, J.S. (2001): El País Valencià en el cens d'Aranda (1768), Universitat Jaume I, Universitat de València, 462 pp.

BELLAVANCE, CL. ; NORMAND, F. (2005) : «Documenter et «informer» les recensements canadiens : le dossier des données contextuelles de 1911 dans l'IRCS», Cahiers québécois de démographie, vol. 34, $\mathrm{n}^{\mathrm{O}}$ 2, pp. 329-347.

BONMATÍ ANTÓN, J.F. (1992): Españoles en el Magreb, siglos XIX y XX, Editorial Mapfre, Madrid, $269 \mathrm{pp}$.

BURRIEL DE ORUETA, E.L. (1980): «Las deficiencias de las fuentes demográficas: el problema del subregistro en Canarias», Estudios Geográficos, núm. 158, XLI, p. 15-46.

CARR, R. (1969): España 1808-1939, Ediciones Ariel, Barcelona, 734 pp.

CUSIDÓ I VALLVERDÚ, T.A.; GIL-ALONSO, F. (2012): «Los censos en España: entre continuidad y cambio (1857-1970), Revista de demografía histórica, XXX, 1, segunda época, pp. 29-67.

EIRAS ROEL, A. (1989): «En torno a la emigración gallega a América en el siglo XIX. Algunas consideraciones a la luz del ejemplo canario», Revista de la Facultad de Geografía e Historia, $\mathrm{n}^{\circ}$ 4, [Universidad de Santiago de Compostela], pp. 225-240.

EIRAS ROEL, A. (1991): «Introducción. Consideraciones sobre la emigración española y portuguesa a América y su contexto demográfico», en Eiras Roel, A., Coord., Emigración Española y portuguesa a América, Instituto de Cultura Juan Gil-Albert, Diputación de Alicante. Seminari d'Estudis sobre la población del País Valencià, 175 p.

EIRAS ROEL, A. (1996): «Cuatro estudios sobre la emigración española a América en la época colonial y algún comentario al margen», Obradoiro de Historia Moderna, nº5, pp. 209-231. Vid. especialmente las páginas 224-231.

FEO PARRONDO, F. (2005): «La epidemia de cólera en San Fernando de Henares (1865)», Nimbus, nº15-16, p. 57-72.

GARCÍA ABAD, R.; PAREJA ALONSO, A.; ZARRAGA SANGRONIZ, K. (2007): «» ¿Sabe leer? ¿Sabe escribir». El proceso de alfabetiazación en el País Vasco (18601930)», Revista de Demografía Histórica, XXV, I, p. 23-58.

GONZÁLEZ PORTILLA, M.; URRUTIKIETXEA LIZARRAGA, J.G. (1987): Vivir en familia, organizar la sociedad. Familia y modelos familiares: las provincias vascas a las puertas de la modernidad (1860). Colaboradora Karmele Zurraga Sangroniz. Servicio Editorial de Universidad del País Vasco, 775 p.

GOZÁLVEZ PÉREZ, V. (1976): La ciudad de Elche. Estudio Geográfico, Departamento de Geografía, Facultad de Filosofía y Letras, Universidad de Valencia, 290 pp. + 8 láms. f.t.

GOZÁLVEZ PÉREZ, V. (1977): El Bajo Vinalopó. Geografía agraria, Universidad de Valencia. Departamento de Geograrfía, 270 p. + VIII láms. f.t.

GOZÁLVEZ PÉREZ, V. (1986): «La natalidad en la provincia de Alicante a principios del siglo XX. Problemas para su evaluación», Cuadernos de Geografía, núm. 39-40, p. 247-262.

GOZÁLVEZ PÉREZ, V. (1997): «La formación del núcleo urbano de Santa Pola (siglos XVIII-XIX)», Nuestra Historia. I Congreso de Historia Local, Santa Pola, Ayuntamiento, p. 151-170. 
GOZÁLVEZ PÉREZ, V. (2011): «Uso de las vías pecuarias y roturaciones: una conflictividad histórica entre ganaderos y labradores», Investigaciones Geográficas, n. 54. p. 101-132.

HORVATH, R. (1991): «Du recensement militaire au recensement universel: le premier recensement en Hongrie (1784-1785)», Population, nº2, 46e année, pp. 279-298.

INVOOD, K.; JAMES, K. (2005): «Unne ressource numérique pour l'analyse historique: le recensement canadien de 1891», Cahiers québécois de démographie, vol. 34, n.2, pp. 315-328.

JULIEN, M. (2008): «La frécuentation scolaire á Québec, 1871-1901: l'effet de l'industrialisation, de l'appartenance culturelle et de la classe social», Cahiers Québécois de Démographie, vol. 37, nº 1 , p. 35-60.

MATÍN RUÍZ, J.F.; DÍAZ RODRÍGUEZ, Ma DEL C. (1985): «La natalidad ilegítima en la formación social canaria: Las repercusiones de la emigración americana», en V Coloquio de Historia canario-americana (1982), Cabildos Interinsulares de las Palmas, Cabildo Insular de Gran Canaria, p. 205-218.

MELÓN, A. (1951): «Los censos de la población en España (1857-1940)», Estudios Geográficos, XII, n ${ }^{\circ} 43,1951$, p. 203-281.

MIKELARENA PEÑA, F. (1992): «Las estructuras familiares en la España tradicional: geografía y análisis a partir del Censo de 1860», Boletín de la Asociación de Demografía Histórica, X, 3, pp. 15-61.

MONTERO ALCAIDE, A. (2009): «La ley de Instrucción Pública (Ley Moyano, 1857)» [en línea]. Cabás: Revista del Centro de Recursos, Interpretación y Estudios en materia educativa (CRIEME) de la Consejería de Educación del Gobierno de Cantabria (España) [publicación seriada en línea], $\mathrm{n}^{\mathrm{o}}$ 1, junio 2009. < http://revista.muesca.es/index.php/ articulos/71-la-ley-de-instruccion-publica-ley-moyano-1857> [consulta: 1-4-2014].

NADAL, F.; MURO, J.I.; URTEAGA, L. (1996): «Los orígenes del Instituto Geográfico y Estadístico», Arbor, CLV, 609-610 (sept.-octubre), pp. 59-91.

NOIN, D. (1988): Géographie de la population, $2^{\mathrm{e}}$ edition, Paris, Masson, $308 \mathrm{pp}$.

PALAZÓN FERRANDO, S. (1995a): Los españoles en América Latina (1850-1990), Fundación Centro Español de Estudios de América Latina (CEDEAL), Madrid, 270 pp.

PALAZÓN FERRANDO, S. (1995b): Capital humano español y desarrollo económico latinoamericano. Evolución, causas y características del flujo migratorio (1882-1990), Generalitat Valenciana. Conselleria d'Educació i Ciència. Institut de Cultura Juan GilAlbert (Diputació Provincial d'Alacant), 405 pp.

PÉREZ PUCHAL, P. (1972): «La población del País Valenciano hasta la época estadística», Cuadernos de Geografía, $\mathrm{n}^{\circ}$ 10, p. 1-30.

RODRÍGUEZ DE GRACIA, H. (2007): «Vicisitudes de un maestro rural (1857-1900). (150 aniversario de la Ley Moyano)», Docencia e Investigación: revista de la Escuela Universitaria de Magisterio de Toledo, año 32, n 17, p. 211-265. Publicación en línea <www. uclm.es/varios/.../docenciaeinvestigacion/pdf/.../Hilario Rodríguez de Gracia> 